EMERSON CESAR DA SILVA GOMES

\title{
REGIME JURÍDICO DA DESPESA PÚBLICA NO BRASIL
}

Tese de Doutorado apresentada à Faculdade de Direito da Universidade de São Paulo como requisito para obtenção do grau de Doutor em Direito Financeiro, elaborada sob a orientação do Professor Livre-Docente Dr. José Maurício Conti

São Paulo 


\section{RESUMO}

GOMES, Emerson Cesar da Silva. Regime Jurídico da Despesa Pública no Brasil. 2013. p. Tese (Doutorado) - Faculdade de Direito, Universidade de São Paulo, São Paulo, 2013.

$\mathrm{O}$ estudo trata do conjunto de regras e princípios que regulam a despesa pública no Brasil, tendo como enfoque principal a disciplina da despesa pública o ponto de vista do gestor público. Constatou-se a necessidade de ampliação do conceito de despesa pública, para abranger a despesa pública no seu aspecto agregado e para abranger as despesas off-budget, tais como, o gasto tributário e os benefícios creditícios. A despesa pública em sentido amplo constitui instrumento para a implementação de políticas públicas. O conceito amplo de despesa público resulta numa diversidade de regimes jurídicos do gasto público, que, entretanto, estão sujeitos a um núcleo comum de princípios jurídicos constitucionais. A diversidade de regimes jurídicos decorre da variedade de organizações estatais e paraestatais sujeitas ao controle financeiro e da variedade de operações que podem ser enquadradas como despesa pública em sentido amplo. Dentre os princípios jurídicos que disciplinam o gasto público, destacam-se os princípios da legalidade, legitimidade, economicidade e transparência. O princípio da legalidade da despesa pública é visto sob diferentes aspectos: a legalidade orçamentária, a legalidade global, a legalidade procedimental e a legalidade específica. Os princípios do gasto público e o contexto da despesa pública constituem recursos para a interpretação das normas e para a integração de lacunas. $\mathrm{O}$ direito dos gastos públicos não pode ser visto como um subconjunto do direito orçamentário, uma vez que o orçamento constitui apenas um dos condicionantes do gasto público, ainda assim, somente dos gastos sujeitos à legalidade orçamentária. $\mathrm{O}$ fenômeno da desorçamentação, a existência de normas de caráter permanente que disciplinam a despesa pública, a possibilidade de alteração e retificação do orçamento pelo poder executivo e a margem de discricionariedade concedida pelas dotações orçamentárias com títulos genéricos evidenciam a reduzida importância da lei orçamentária na disciplina do gasto público.

Palavras-chave: Despesa Pública. Gasto Público. Orçamento. Transferência Voluntária. Despesa Obrigatória. Diretrizes Orçamentárias. Plano Plurianual. Política Pública 


\begin{abstract}
GOMES, Emerson Cesar da Silva. Regime Jurídico da Despesa Pública no Brasil. 2013. p. Tese (Doutorado) - Faculdade de Direito, Universidade de São Paulo, São Paulo, 2013.

This study deals with the set of rules and principles governing public spending in Brazil, with the main focus on the public manager's point of view. It concluded to be necessary to expand the concept of public spending to cover public spending in aggregate and to cover off-budget expenditures, such as the tax expeditures and the loans benefits. The public spending in the broad sense is an instrument for implementation of public policies. The broad concept of public spending results in a diversity of legal systems of public expenditure, which, however, are subject to a common core of constitutional legal principles. Different legal regimes stems from the variety of state and parastatal organizations subject to financial control and the variety of operations that can be classified as public expenditure broadly. Among the legal principles governing public spending, we highlight the principles of legality, legitimacy, economy and transparency. The principle of legality of public expenditure is seen under different aspects: the budget legality, global legality, procedural legality and legal reservation. The principles of public spending and the context of public expenditure are resources for norm interpretation and for the integration of legal gaps. The public expenditures law cannot be seen as a subset of the budget law, once the budget is only one of the determinants of public spending, and even though, only the spending subject to budgetary legality. The phenomenon of off-budget expenditures, the existence of permanent rules governing public expenditure, the possibility of amendment and correction of the budget by the executive power and the discretion granted by the budgetary allocations with generic titles show the reduced importance of the budget law to the legal discipline of public spending.
\end{abstract}

Keywords: Public Expenditure. Budget. Voluntary Transfers. Grants. Mandatory Expenditures. Public Policy. 


\section{INTRODUÇÃO}

O objeto desta pesquisa é o regime jurídico da despesa pública no Brasil. Trata-se do estudo sobre o conjunto de regras e princípios que regulam o instituto da despesa pública ${ }^{1}$.

Pretende-se analisar este objeto, principal, mas não exclusivamente, sob o ponto de vista do gestor público e do controle financeiro, para os quais importa conhecer os critérios que permitam determinar se uma determinada despesa pública está ou não de acordo com o ordenamento jurídico.

Pressuposto fundamental da presente discussão é o caráter jurídico da despesa pública, sem deixar de reconhecer o seu componente político. A execução da despesa pública, mais precisamente, a decisão de gastar, é uma conduta humana, que se sujeita aos limites previstos no Direito, tendo em vista o atendimento das necessidades públicas.

Num Estado Democrático de Direito, no qual o princípio da legalidade não está restrito às intervenções na liberdade individual ${ }^{2}$, a despesa pública não poderia ser um "espaço livre de direito", concedendo-se uma margem de discricionariedade (ou de arbítrio) excessivamente ampla ao gestor público (e, também, ao agente político que eventualmente exerce atividade administrativa).

Reforça este argumento o fato de a maior parte dos recursos utilizados para fazer face aos gastos públicos ser de origem tributária e, portanto, de exigência compulsória dos cidadãos contribuintes.

De fato, na etapa de realização da despesa pública, o elemento "juridico" deve se sobrepor ao "político"3, pois a despesa pública está condicionada a uma série de regras e princípios jurídicos.

\footnotetext{
${ }^{1}$ Neste trabalho, utilizamos também a expressão "gasto público" como sinônima de "despesa pública", sem efetuar qualquer distinção entre as mesmas.

${ }^{2}$ Hartmut Maurer, ilustre administrativista alemão, salienta que "a limitação da reserva de lei à administração de intervenção está antiquada. O desenvolvimento da democracia parlamentar, o significado crescente da administração de prestação e a penetração jurídico-constitucional em todos os âmbitos estatais pela Lei Fundamental exigem sua extensão". Conclui que: "as decisões fundamentais e importantes para a coletividade assim como para o cidadão particular devem ser tomadas pelo dador de leis e ser por ele respondidas" (MAURER, 2006) .

${ }^{3}$ Nesta fase, o componente "político" reduz a sua participação na decisão de gasto, mas não é desprezível, uma vez que as autorizações orçamentárias são estipulações genéricas, mas que conferem, inda, grande margem de liberdade ao administrador. Existem, ainda, Programas de Trabalho constantes do Orçamento vulgarmente denominados "PTs Guarda-Chuva" que podem abarcar uma variada gama de projetos ou ações. A margem de remanejamento conferida nas Leis Orçamentárias ao chefe do Poder Executivo também evidencia da existência de um componente político na fase de execução orçamentária.
} 
A decisão de gastar vincula-se à lei orçamentária anual (LOA), na qual estão previstas dotações, que estabelecem os objetivos e as metas a serem perseguidos pela unidade orçamentária, atribuindo-lhes um teto de recursos financeiros para o atingimento de uma finalidade num determinado período de tempo (exercício financeiro). Estas dotações estão escritas na "linguagem das classificações orçamentárias", as quais estabelecem uma série de condicionantes ao gasto público, podendo constituir-se em verdadeiros mandamentos legais (vide item 8.1.3).

Entretanto, a despesa não se vincula exclusivamente às condicionalidades contidas na lei orçamentária anual. Há uma série de regras contidas em outras fontes normativas, algumas de caráter permanente, que disciplinam a realização da despesa ${ }^{4}$ (vide capítulo 6).

Por exemplo, a execução da despesa vincula-se à lei de diretrizes orçamentárias (LDO), que, no seu mister de orientar a elaboração da lei orçamentária anual, incide, ainda que indiretamente, na fase da execução da despesa pública ${ }^{5}$.

Vincula-se às normas gerais de direito financeiro, tais como as constantes da Lei $n^{\circ} 4.320 / 64$, que estabelece requisitos para a concessão de subvenções, sociais e econômicas, que define o procedimento geral para execução da despesa pública e que regula a contabilidade pública, inclusive da despesa.

Vincula-se aos princípios constitucionais da despesa pública, traduzidos na Constituição Federal como aspectos do controle exercido pelos Tribunais de Contas (art. 70, CF/88) e aos princípios da Administração Pública (art. 37, caput, da $\mathrm{CF} / 88)$

Vincula-se, ainda, aos chamados "princípios orçamentários", alguns dos quais de estatura constitucional, que podem incidir, por via reflexa, também na realização da despesa pública ${ }^{7}$.

\footnotetext{
${ }^{4}$ Neste estudo, foram identificados diversos traços de autonomia do instituto em relação ao orçamento e à receita pública, sem, entretanto, desconsiderar o papel do orçamento como determinante da despesa pública.

${ }^{5}$ A título de exemplificação, o art. 21 da Lei n ${ }^{\circ}$ 12.017/2009 (Lei de Diretrizes Orçamentárias relativa ao exercício de 2010), dispõe que não poderão ser destinados recursos para atender despesas relativas a uma série de itens de gasto. Dirigido especialmente à elaboração do orçamento, este dispositivo impede que, constem na LOA dotações orçamentárias específicas para o atendimento das despesas mencionadas na lei. Nada obstante, esta disposição aplica-se, também, à execução orçamentária, uma vez que não poderão ser gastos recursos públicos federais nestes itens de gastos, independentemente da rubrica orçamentária. Interpretação diversa seria uma forma de contornar a proibição e de desvirtuar o "espírito" da LDO.

${ }^{6}$ Antônio L. Souza Franco chama de "regras orçamentais" o que os textos de orçamento público costumam chamar de "princípios orçamentários"(FRANCO, 2002).

${ }^{7}$ Carrera Raya salienta que os "principios presupuestarios son un conjunto de reglas jurídicas que deben inspirar la elaboración, aprobación, ejecución y control del Presupuesto" (RAYA, 1995). No nosso
} 
O regime da despesa pública não se restringe aos desembolsos realizados em decorrência da utilização dos créditos orçamentários e adicionais.

As despesas operacionais de empresas estatais, por exemplo, não estão sujeitas aos condicionantes da Lei Orçamentária Anual (LOA) do ente federativo ao qual integram, mas representam um volume expressivo de recursos, sob a gestão de agentes públicos em sentido amplo.

Acerca destas entidades, a LOA abrange exclusivamente "o orçamento de investimento das empresas em que a União, direta ou indiretamente, detenha a maioria do capital social com direito a voto" (art. 165, §5 , II, CF/88). Ademais, as LDOs federais têm excluído, ainda, as empresas estatais do "regime contábil, execução do orçamento e demonstrações contábeis" estabelecido na Lei $\mathrm{n}^{\circ} 4.320 / 64$ (vide, por exemplo, o art. 54, $\S 6^{\circ}$, da Lei $\left.\mathrm{n}^{\circ} 12.017 / 2009\right)$.

Como entes integrantes da Administração Pública Indireta, não se pode admitir que as estatais, alvos frequentes de interferências políticas e de escândalos por má-gestão, possam gerir seus recursos financeiros sem submissão a uma disciplina jurídica mínima.

Além disso, há despesas que não envolvem o desembolso real de recursos públicos, não sujeitas ao princípio da legalidade orçamentária, tais como, os gastos tributários (tax expenditures) e os benefícios creditícios, podem estar sujeitos a outras regras e princípios jurídicos.

Por outro lado, a despesa pública não se encerra apenas em um ato. Ela pode ser vista como um processo que se inicia com a definição de uma política pública e se encerra com a despesa pública. Pode-se falar num processo de concretização da despesa pública: uma sucessão de atos relacionados entre si, na qual um ato pode ser decorrência do outro ou ainda, um ato de controle do anterior. Neste sentido, um vício ou ilegalidade numa etapa pode contaminar as etapas seguintes.

A Lei $\mathrm{n}^{\circ} 4320 / 1964$ regulamenta apenas uma parte do procedimento de realização da despesa pública, abrangendo os atos de empenho, liquidação e pagamento. A Lei $\mathrm{n}^{\circ}$ 4.320/1964 é aplicável às despesas orçamentárias realizadas pela administração direta, pelas autarquias, fundações públicas e empresas estatais fases do ciclo orçamentário. Sua aplicação, ademais, é indireta, tal como ocorre com a Lei de Diretrizes Orçamentárias (LDO). Será objeto de estudo a análise de como se aplicam os princípios orçamentários à fase de execução da despesa (item 7.5). 
dependentes. No plano federal, as empresas estatais integrantes do Orçamento de Investimento das Estatais não estão sujeitas às normas gerais atinentes ao regime contábil, de execução do orçamento e de demonstrações contábeis previstas na referida lei ${ }^{8}$.

Esta exposição sugere a necessidade de considerarmos a despesa pública como sendo não somente a despesa orçamentária, mas também as chamadas "off-budget expenditures" pela literatura estrangeira.

Ocorre que, ao ampliarmos a categoria jurídica "despesa pública", haverá diversos regimes jurídicos da despesa pública, relacionados à diversidade de órgãos e entidades, estatais e paraestatais, e relacionados à diversidade de operações que podem ser abrangidas por esta categoria, tais como, os gastos tributários e os benefícios creditícios.

Esta diversidade compartilha, entretanto, de um núcleo de princípios comum a todos os regimes, derivado, especialmente, dos princípios constitucionais gerais, dos princípios da administração pública e a submissão das entidades ao controle do Tribunal de Contas (art. 70, CF/88).

Este trabalho aborda os aspectos jurídicos da despesa pública, mas sem olvidar que o gasto público pode constituir objeto ou pode ser visto do ponto de vista de diversas ciências (a economia, a contabilidade, a ciência da administração, a ciência política e a sociologia) que podem fornecer subsídios à interpretação das normas e à integração de lacunas.

\subsection{Importância do tema}

O regime jurídico da despesa pública é um tema cuja presença é escassa nos textos jurídicos brasileiros. Carecem estudos aprofundados e sistematizados sobre o direito dos gastos públicos, não só aqui no Brasil como no exterior.

Nos compêndios de direito financeiro, os autores limitam-se a tratar da conceituação da despesa pública, das suas classificações e, quando muito, abordam o procedimento geral de execução orçamentária (autorização, empenho, liquidação e pagamento), conforme previsto na Lei $n^{\circ}$ 4.320/1964, ou seja, um aspecto procedimental.

Ademais, o tema gasto público é sempre visto como uma fase do ciclo orçamentário e a sua disciplina jurídica é abordada como um mero apêndice do direito

\footnotetext{
${ }^{8}$ Vide, por exemplo, o art. 54, $\$ 6^{\circ}$, da Lei ${ }^{\circ} 12.017 / 2009$ (LDO 2010).
} 
orçamentário, sem traços de autonomia científica. De fato, ao menos no Brasil, é que é mais comum encontrar a expressão "execução orçamentária” que a expressão "execução do gasto público", ou ainda, "controle da execução orçamentária" que "controle do gasto público". Além disso, a doutrina costuma relacionar os princípios orçamentários e não os princípios do gasto público.

Com o advento da Lei de Responsabilidade Fiscal (LRF), este cenário começou a mudar e os autores passaram a abordar questões como a disciplina das despesas de pessoal (arts. 19 e 20), da geração de despesa (art. 16) e das despesas de caráter continuado (art. 17). Isto se deve, muito provavelmente, em razão de a lei disciplinar de forma mais densa o gasto público e, em muitas ocasiões, sem relacioná-lo diretamente com o orçamento público, como é o caso dos supramencionados dispositivos.

A carência de estudos jurídicos sistematizados sobre despesa pública constitui um incentivo para o uso irracional dos recursos públicos. O que se observa, na prática, é que muitos agentes políticos e gestores públicos consideram o gasto público como uma matéria de cunho exclusivamente político, condicionada apenas aos preceitos de natureza formal (procedimento previsto na Lei $n^{\circ}$ 4.320/1964) e à existência de dotação orçamentária.

Constitui evidência desta afirmação a aprovação na Câmara dos Deputados, em $2^{\circ}$ turno, da Proposta de Emenda Constitucional que institui o "orçamento impositivo" (PEC $\mathrm{n}^{\circ}$ 565/06), tornando obrigatória a execução de emendas parlamentares ao orçamento, PEC contra a qual tecemos duras críticas no item 13.3.

A legislação relativa à despesa pública é extremamente complexa e assistemática, abrangendo uma enorme diversidade de fontes que abordam, direta ou indiretamente, o tema (vide capítulo 60).

Apenas a título de exemplificação, convém citar o seguinte rol:

a) Constituição Federal;

b) Leis Complementares, tais como, a Lei de Responsabilidade Fiscal, a Lei Complementar $\mathrm{n}^{\circ} 141$ e a Lei $\mathrm{n}^{\circ} 4.320 / 1964$ (que tem status de lei complementar);

c) Leis temporárias que estabelecem o Plano Plurianual, as Diretrizes Orçamentárias e o Orçamento anual;

d) Leis ordinárias, tais como, a Lei 8.666/1993 (normas gerais sobre licitações e contratos); 
e) diversos Decretos, Regulamentos, Instruções Normativas e Portarias Interministeriais;

f) normas de utilização de sistemas informatizados de administração financeira, tais como, o SIAFI;

g) pareceres da AGU e jurisprudência dos Tribunais de Contas, etc.

Embora complexa a legislação, em inúmeras situações concretas enfrentadas no dia-a-dia, ela não proporciona uma solução direta e expressa para orientar sua conduta do gestor público de boa fé, que está sujeito aos questionamentos dos órgãos de controle interno e externo e do Poder Judiciário. O administrador público de boa fé padece, portanto, de enorme insegurança jurídica. Ademais, nem sempre as normas legais ou infralegais se compatibilizam com as normas de hierarquia superior, tornando ainda mais difícil determinar o Direito aplicável ao caso concreto.

No nosso entendimento, as referidas lacunas devem ser supridas pelos princípios gerais que regem a administração pública (art. 37, caput, CF/88) e pelos princípios específicos aplicáveis à gestão de recursos públicos (art. 70, caput, CF/88), além de outros que, por seu status constitucional, e pelo seu grau de abstração e generalidade, asseguram a completude do direito dos gastos públicos (vide item 12.2).

Nada obstante, a ausência de estudos jurídicos aprofundados compromete a eficácia dos referidos dispositivos constitucionais. Ademais, os princípios supramencionados são vistos sempre sob a ótica do controle, mas não como diretrizes a serem seguidas pelo administrador.

Nos processos do Tribunal de Contas da União, são comuns alegações de inexistência de norma expressa para justificar gastos completamente desvirtuados da sua finalidade pública, o que evidencia a necessidade de reforçar o papel dos princípios como diretrizes para orientar a atuação do gestor público.

O direito dos gastos públicos serve de base para o estudo das diversas modalidades de responsabilidades na gestão pública, em especial, da responsabilidade financeira, definida como (GOMES, 2012, p. 35-36):

\footnotetext{
“a obrigação de repor recursos públicos (imputação de débito) ou de suportar as sanções previstas em lei, no âmbito do controle financeiro exercido pelos Tribunais de Contas, em razão da violação de normas pertinentes à gestão de bens, dinheiros públicos ou dos recursos privados sujeitos à guarda e administração estatal”.
}

De fato, a violação ao regime jurídico da despesa pública constitui um pressuposto, uma condição necessária (e não suficiente) para a aplicação pelo Tribunal 
de Contas das sanções previstas em lei. Neste sentido, a Constituição Federal de 1988 estabeleceu, no art. 71, VIII, que compete ao Tribunal de Contas "aplicar aos responsáveis, em caso de ilegalidade de despesa ou irregularidade de contas, as sanções previstas em lei, que estabelecerá, entre outras cominações, multa proporcional ao dano causado ao erário" (grifo nosso).

\subsubsection{Situação das Finanças Públicas do Brasil}

Neste tópico, foram ressaltadas as razões jurídicas pelas quais é importante estudar o direito dos gastos públicos no Brasil. Outros argumentos de natureza extrajurídica reforçam a necessidade do estudo. De fato, a situação das finanças públicas no Brasil é preocupante e as recentes práticas financeiras e contábeis do setor público estão minando a credibilidade fiscal do país.

Um dos temas que tem chamado a atenção recentemente é o da contabilidade criativa do setor público. Em linguagem coloquial, corresponde ao conjunto de manobras e truques que o Governo Federal vem praticando com vistas a apresentar as contas públicas, em especial, o resultado primário do setor público, de uma forma melhor do que elas realmente são.

Os truques do Governo Federal abrangem, por exemplo, o adiamento de pagamentos a fornecedores, o recebimento antecipado do pagamento de dividendos de bancos e empresas estatais e a multiplicação de receitas extraordinárias (FUCS, 2013).

Uma operação triangular foi realizada pelo Governo Federal com os Bancos Públicos. Por ela, o Tesouro emite títulos públicos (aumentando a dívida pública bruta), repassa os papeis para Bancos oficiais como o BNDES e a Caixa Econômica Federal, por prazos a perder de vista, para que estes bancos possam oferecer mais empréstimos aos clientes. Em razão disso, há um aumento nos dividendos repassados dos bancos oficiais para o Tesouro, aumentando artificialmente o superávit primário. Com efeito, os dividendos pagos à União pelos bancos oficiais e empresas estatais passaram de 0,20\% do PIB/ano, no período de 2001 a 2005, para 0,37\% do PIB/ano, no período de 2006 a 2008 (FUCS, 2013).

Outra manobra contábil extravagante ocorreu na capitalização da Petrobrás em 2010. Neste exercício financeiro, o superávit primário do Tesouro só foi alcançado em razão da antecipação de receitas pagas pela Petrobrás ao Tesouro, com base na exploração futura de 5 bilhões de barris de petróleo. Dos 75 bilhões de reais pagos pela Petrobrás, R $\$ 43$ bilhões foram usados para comprar ações da própria empresa em oferta 
pública com o objetivo de aumentar a participação da União no capital da companhia. A diferença, R\$ 32 bilhões, foi usada para compor o superávit primário da União, sem a qual haveria déficit primário de R\$ 6 bilhões (FUCS, 2013).

O próprio abatimento das despesas do PAC para fins de apuração do superávit primário, apesar de ser permitido pela Lei de Diretrizes Orçamentárias, tem sido criticado por economistas por desvirtuar o próprio conceito de resultado primário 9 .

Nos últimos meses de 2013, o resultado do setor público consolidado, que tem apresentado resultados primários ruins, tendo apresentado até mesmo déficit em setembro/ $2013^{10}$.

Além destes fatores, a ameaça inflacionária, o baixo crescimento econômico, o aumento da dívida pública e o possível ressurgimento dos "esqueletos" (dívidas não contabilizadas) são outros que levantam novas preocupações com o estado das contas públicas do país e que afetam a credibilidade internacional do país.

Um outro aspecto que merece ser destacado é a importância dos benefícios tributários, financeiros e creditícios nas finanças da União. No Relatório e Parecer Prévio sobre as Contas do Governo da República - Exercício de 2012, o Tribunal de Contas da União aponta que o total destes benefícios alcançou o montante estimado de $\mathrm{R}$ \$ 216,5 bilhões, valor superior à soma das despesas orçamentárias nas funções saúde e educação (R\$ 143,8 bilhões) no mesmo exercício. No exercício de 2011, o montante foi de R 210 bilhões, valor superior à soma das despesas orçamentárias nas funções saúde, educação e assistência social. Em 2003, o conjunto dos benefícios tributários, financeiros e creditícios era de $\mathrm{R} \$ 58,6$ bilhões, correspondente a 22,65\% dos gastos diretos realizados por intermédio dos orçamentos da União.

Portanto, o fenômeno das "off-budget expenditures" (desorçamentação), ilustrado por estes benefícios, é mais um assunto que merece tratamento mais rigorosa pelo Direito.

\footnotetext{
${ }^{9}$ Vide, a propósito, o artigo do Economista Mansueto Almeida do IPEA "Superávit Primário: Descanse em Paz", publicado no Jornal Valor Econômico de 28/10/2013. Disponível em http://mansueto.wordpress.com/2010/10/28/superavit-primario-descanse-em-paz/.

${ }_{10} \mathrm{Cf}$. http://veja.abril.com.br/noticia/economia/brasil-registra-o-pior-deficit-primario-para-meses-desetembro.
} 


\subsection{Contribuição da Tese à Ciência Jurídica Brasileira}

A primeira contribuição deste trabalho à ciência jurídica nacional refere-se à discussão sobre a autonomia ou não da despesa pública em relação ao orçamento público, o que pode plantar as sementes de um direito dos gastos públicos no Brasil.

É na Espanha que os estudos sobre o "derecho de los gastos públicos” alcançaram maior desenvolvimento. Na Constituição Espanhola, estão expressos os princípios do gasto público no artigo 31 , apartado $2^{\circ}$ ("el gasto público realizará una asignación equitativa de los recursos públicos, y su programación y ejecución corresponderán a los critérios de eficacia y economia”), diversamente da brasileira ou da alemã que os coloca como aspectos do controle (Prüfungsmasstäbe).

Juan José Bayona de Perogordo e María Teresa Soler Roch são alguns dos maiores defensores da instituição do gasto público autônomo em relação ao orçamento público (PEROGORGO; ROCH, 1989):

"Sin desconocer la conexión existente entre ambos institutos jurídicos creemos que el gasto público es susceptible de una ordenación jurídicomaterial que trascienda el ámbito jurídico-formal en que, sustancialmente, se desenvuele el régimen jurídico del Presupuesto".

É importante ressaltar que, mesmo na literatura estrangeira, há quem inclua o Direito dos Gastos Públicos como ramo do Direito Orçamentário ${ }^{11}$ e há quem apresente o Direito Orçamentário como ramo do Direito dos Gastos Públicos (por exemplo, José Pascoal Garcia).

Miguel Ángel Collado Yurrita, por seu turno, identifica o Direito dos Gastos Públicos como o Direito Orçamentário (YURRITA, 1996):

"En efecto, el Derecho Presupuestario debe ser considerado como el Derecho
de los gastos públicos, como El conjunto de normas que regulan la gestión,
administración y erogación de los recursos económicos del Estado y demás
entes públicos, teniendo presente que la realización de los gastos públicos

\footnotetext{
${ }^{11}$ José Juan Ferreiro Lapatza considera que o orçamento é a instituição central do estudo jurídico do gasto público. Segundo o autor (LAPATZA, 2004): "El gasto público está, a sua vez, normalmente disciplinado en nuestro ordenamiento, por una parte, por normas estables, permanentes, que regulan el contenido, la formación, la ejecución y el control de la ejecución del presupuesto, y por otra parte, por el propio presupuesto, que periódicamente determina, con carácter de norma jurídica, las cantidades a gastar y las finalidades del gasto. Tal determinación puede hacerse en forma más o menos flexible. Así, el presupuesto puede destinar una cantidad exacta y no ampliable a la realización de un gasto determinado, o bien puede, por ejemplo disponer que un gasto se realizará en la cuantía en que se realice un determinado ingreso. De cualquier forma es el presupuesto, son las normas juridicas que en él presupuesto, son las normas jurídicas que en él se contienen las que fijan los limites y fines del gasto para cada ejercício. № es extraño así que el presupuesto se haya configurado como la institución central, como el núcleo en el estudio jurídico del gasto público, hasta el punto de que el Derecho del gasto público, el conjunto de normas que lo regulan, se ha entendido casi siempre como Derecho presupuestario" (grifo nosso).
} 
aparece ligada a la ejecución de los fines de la comunidad, lo cual significa que la asignación de los recursos públicos está determinada por los principios, los objetivos y los fines que en un momento histórico dado la Constitución reconoce como fines y necesidades públicos".

No nosso entendimento, existem fortes argumentos no sentido de se considerar o gasto público como categoria autônoma, a despeito dos vínculos já mencionados com o orçamento (vide capítulo 16).

Uma segunda contribuição corresponde à abordagem do gasto público considerado em sentido amplo, destacando a existência de diversos regimes jurídicos da despesa pública, mas com um núcleo comum de princípios.

A conceituação da despesa pública em sentido amplo abrange também os dispêndios ou desembolsos de recursos financeiros realizados por diversos entes que orbitam em torno do Estado e se submetem ao controle exercido pelos Tribunais de Contas e aos princípios do gasto público, tais como, as empresas estatais, as organizações sociais, as OSCIPs, o Sistema S (SESC, SENAC, etc), entidades privadas que celebram convênios ou contratos de repasse com o Poder Público e os bancos públicos de fomento.

Trata-se, portanto, da criação de uma categoria jurídica mais ampla (despesa pública em sentido amplo), na qual estão inseridas categorias sujeitas a tratamentos jurídicos mais específicos (despesas realizadas por empresas estatais, por entidades paraestatais, gasto tributário, benefícios creditícios, etc.).

Uma terceira contribuição compreende o estudo sistemático das fontes do direito dos gastos públicos no Brasil, que, conforme já mencionado, envolve normas constitucionais até normas infralegais (regulamentos, resoluções, portarias, instruções normativas, etc.), normas temporárias (lei orçamentária, LDO, PPA) até normas de caráter permanente. Deve ser ressaltada a influência das classificações orçamentárias presentes na LOA na decisão de gastar (capítulo 6).

Uma quarta contribuição à ciência jurídica brasileira diz respeito aos diversos planos ou aspectos que se desenvolve o princípio da legalidade da despesa pública no Brasil (capítulo 8): legalidade orçamentária, legalidade "global” ou agregada, legalidade procedimental e legalidade específica (reserva legal) ${ }^{12}$.

12 Em Portugal, Antônio L. Souza Franco já aponta para os diversos aspectos do princípio da legalidade (FRANCO, 2002): "No plano jurídico, a execução do orçamento exige respeito pela legalidade substancial. Ela resulta do respeito pelo acto ou actos que integram o orçamento (lei e orçamento de serviço) e por todos os outros actos praticados pela administração; tanto como leis sobre a organização e 
O estudo sobre o princípio não é sem propósito, haja vista que, diversos dispositivos legais e constitucionais fazem menção à ilegalidade da despesa. O art. 10, inciso IX, da Lei $n^{\circ}$ 8.429/92 (lei de improbidade administrativa) dispõe que consiste de ato de improbidade administrativa que causa dano ao erário "ordenar ou permitir a realização de despesa não autorizadas em lei ou regulamento”. O art. 359-D do Código Penal (incluído pela Lei $\mathrm{n}^{\circ} 10.028 / 2000$ ) tipifica a conduta de “ordenar despesa não autorizada em lei" como crime contra as finanças públicas. Segundo o art. 71, inciso VIII, da CF/88, compete aos Tribunais de Contas aplicar as sanções previstas em lei em caso de "ilegalidade da despesa". Por fim, o art. 16, inciso III, alínea $\underline{\mathrm{b}}$, da Lei $\mathrm{n}^{\circ}$ 8.443/92 (Lei Orgânica do Tribunal de Contas da União), estabelece que, no caso de prática de ato de gestão ilegal, o TCU poderá julgar irregulares as contas do responsável.

\subsection{Principais questões analisadas}

A partir do objeto da pesquisa, o regime jurídico da despesa pública no Brasil, foi possível definir as principais questões debatidas neste trabalho.

Em primeiro lugar, conceituar o fenômeno "despesa pública" ou "gasto público". Cuida-se de uma questão de extrema importância: a delimitação do objeto que será regulado pelas normas jurídicas que, por sua vez, serão objeto deste trabalho.

Se o conceito for muito amplo, teremos, de fato, diversos "regimes de gastos públicos", pois as normas não se aplicarão igual ou uniformemente em todo escopo do objeto. Por outro lado, se for muito restrito, o conceito jurídico não irá explorar a completa dimensão do fenômeno real, ou seja, o objeto disciplinado poderia ser expandido sem que houvesse alteração no conjunto de normas que o disciplinam. Além disso, um conceito limitado que não leve em conta todo o processo de concretização da despesa pública não será útil para saber se uma determinada despesa está ou não de acordo com o ordenamento jurídico, pois sua juridicidade está apoiada em atos/fatos/negócios jurídicos que precedem o desembolso de recursos públicos.

São diversos os desdobramentos ou questionamentos que podem surgir a partir dessa questão principal, tais como:

funcionamento da Administração, como porque a organização e funcionamento da Administração, como porque a adequação orçamental é uma forma de legalidade que se projecta nas relações entre os particulares e a Administração (leis definidoras de direitos: dos contribuintes, dos funcionários, dos beneficiários de despesas, etc.)". 
a) existem conceitos ou definições legais ou doutrinárias sobre despesa ou gasto público?

b) o gasto público consiste de um ato ou de um procedimento administrativo tendente à utilização dos recursos públicos financeiros?

c) o gasto tributário e os demais benefícios creditícios devem ser considerados gastos públicos?

d) o gasto público deve ser considerado em seu aspecto global/agregado ou no seu aspecto individual?

e) quais são os elementos essenciais do gasto público? O tipo de operação, a presença de um agente público, a exigência de autorização legislativa, a aplicação de dinheiro público são elementos essenciais ao conceito de gasto público?

A segunda questão principal foi a identificação das regras e princípios a que estão sujeitos os gastos públicos no Brasil. Como se pode perceber, a questão está intrinsecamente relacionada com a questão anterior, pois não se pode conceituar definitivamente a despesa pública, sem conhecer o âmbito de aplicação das normas que compõem a disciplina jurídica da despesa pública.

Para a solução dessa questão, foi necessário:

a) identificar as fontes do direito dos gastos públicos no Brasil;

b) identificar os critérios de interpretação das normas atinentes à despesa pública;

c) identificar os critérios de colmatação de lacunas.

A última questão principal consistiu em verificar se o direito dos gastos públicos no Brasil é autônomo em relação ao direito orçamentário. Para isso, foi necessário identificar os vínculos existentes entre o gasto e o orçamento público, questionando se o orçamento público ainda é a instituição central do regime jurídico da despesa pública.

\subsection{Metodologia}

A presente pesquisa foi realizada mediante a utilização de diversas técnicas ou métodos, considerado o caráter multifacetado do objeto do estudo: o gasto público.

Em primeiro lugar, deverá ser realizada pesquisa bibliográfica dos principais textos da doutrina e artigos de direito financeiro abordando o tema do gasto e 
do orçamento públicos. Sempre que necessário, recorreu-se, também, à doutrina brasileira de direito constitucional e administrativo.

A pesquisa na legislação brasileira estará concentrada legislação nacional e federal que incide, direta ou indiretamente, nos gastos públicos. A pluralidade de normas de diferentes hierarquias que impactam, direta ou indiretamente, no gasto público requer que o escopo do estudo da legislação seja restringido, mormente num país de dimensão continental que conta com 26 Estados, um Distrito Federal e mais de 5000 municípios, todos com competência legislativa concorrente em matéria financeira (art. 24, inciso I, c/c art. 30, incisos I e II, da CF/88).

Em terceiro lugar, deverá ser utilizado o método comparativo, mediante recurso à doutrina e à legislação estrangeiras, em especial, no que tange ao estudo dos princípios da despesa pública, os critérios de controle da gestão pública, os princípios orçamentários e aos principais institutos relacionados ao gasto público de países, tais como, Espanha, Portugal e Alemanha.

Por fim, será utilizada também a consulta de deliberações e relatórios dos Tribunais de Contas e de julgados do Poder Judiciário, com vistas a verificar, no caso concreto, como tem sido a aplicação das normas atinentes ao gasto público.

\subsection{Premissas adotadas}

A primeira premissa adotada neste estudo diz respeito ao caráter jurídico da despesa pública. A decisão de gastar não é uma decisão exclusivamente política, conforme revelam os autores a seguir.

Germán Orón Moratal aponta que o método jurídico tem sido o grande ausente na análise do gasto público, salvo algumas exceções. Segundo o autor, no Direito, há um desequilíbrio em favor dos estudos sobre os ingressos públicos, notadamente os tributários, em relação aos gastos públicos (MORATAL, 1995).

Moratal argumenta que as decisões do gasto público são frequentemente abandonadas pelo jurista sob pretexto de constituírem autênticas manifestações políticas. Utiliza-se, segundo autor, de um silogismo equivocado: se a decisão do gasto público é adotada pelo órgão soberano ou os mandatários do povo, e estes, por sua condição, são essencialmente políticos, então, a decisão de gasto seria, também, uma decisão política (MORATAL, 1995).

Considerações como esta tem sido a razão pela qual as atenções estão voltadas preponderantemente para os procedimentos orçamentários, à elaboração do 
orçamento, à execução do gasto público, ao princípio da legalidade e às funções do controle externo e interno. Em escassas ocasiões, se tem abordado a legitimidade de determinados gastos ou a vinculação jurídica dos poderes públicos para atender certas necessidades ou atende-las de um modo determinado (MORATAL, 1995).

Assim, conclui que a decisão do gasto público, como manifestação da atividade financeira, é essencial, mas não exclusivamente, política, constituindo-se claramente no objeto do Estado do Direito Financeiro. Por outro lado, salienta que este elemento jurídico do gasto não deve ser limitado aos aspectos formais, abarcando também critérios de justiça (materiais) que não poderiam ser ignorados ou substituídos por exigências de racionalidade econômica (MORATAL, 1995).

Maria d'Oliveira Martins, por sua vez, destaca que a despesa pública, em termos dogmático e jurídico, foi por muito tempo entendida como um tema menor. Segundo a autora, isto se deve, em parte, à influência da escola alemã de direito público, que remetia o tratamento da despesa pública para o domínio político, considerando as normas sobre despesa pública como internas ou de pura organização, as quais não tinham, como tal, natureza jurídica (MARTINS, 2012).

A autora, citando Cazorla Prietro, também destaca o hiato em termos de desenvolvimento entre os dois braços do direito financeiro: o das receitas, amplamente tratado, e o das despesas, com inúmeras matérias a desbravar (MARTINS, 2012).

Por fim, Martins destaca a importância do controle da despesa pública, nos dias atuais, muito por força da necessidade de cumprimento dos critérios de convergência do endividamento e déficit orçamentário, remete a matéria necessariamente para o plano jurídico (MARTINS, 2012).

A segunda premissa diz respeito à lei orçamentária anual. A lei orçamentária anual não cria direitos subjetivos aos administrados.

Esta premissa está fundada no princípio ou regra orçamentária da exclusividade, segundo a qual o Orçamento "não conterá dispositivo estranho à previsão da receita e à fixação da despesa, não se incluindo na proibição a autorização para abertura de créditos suplementares e contratação de operações de crédito, ainda que por antecipação de receita, nos termos da lei” (art. 165, §8 $8^{\circ}, \mathrm{CF} / 88$ ).

Segundo o Professor Regis Fernandes de Oliveira, a exclusividade significa que "não pode o texto da lei orçamentária instituir tributo, por exemplo, nem qualquer outra determinação que fuja às finalidades específicas de previsão de receita e fixação de despesa” (OLIVEIRA, 2006, p. 326-327). As únicas exceções previstas na CF/88 
são a autorização para abertura de créditos suplementares e a autorização para contratação de operações de crédito.

A lei orçamentária anual é entendida como um mecanismo pelo qual a sociedade faz escolhas de que necessidades públicas serão atendidas num cenário de escassez, não sendo veículo adequado para a instituição de direitos subjetivos.

A criação de direitos subjetivos exige definir, pelo menos, quem são os beneficiários, quais são os requisitos/condições para aquisição do direito, qual a prestação correspondente ao direito, as hipóteses em que há a perda daquele direito e contra quem o direito subjetivo é oponível. O orçamento, por sua vez, está escrito na "linguagem das classificações orçamentárias" que não é apta a atender a estes requisitos e nem pode, por força do princípio da exclusividade supramencionado.

Portanto, a criação de direitos subjetivos, de natureza pecuniária ou não, deve ser feita por outras leis, preferencialmente, as de natureza permanente.

\subsection{Limitações do Trabalho}

O presente estudo está restrito à legislação federal e nacional brasileira, não abrangendo a legislação produzida pelos entes subnacionais (Estados, Distrito Federal e Municípios).

Como se poderá observar, a legislação federal ou nacional em matéria de gastos públicos é extensa. Desta forma, incluir neste objeto de estudo a legislação de 26 Estados e Distrito Federal, tornaria inviável a presente pesquisa. Seria ainda mais inviável se fosse considerada a legislação de mais de 5000 municípios.

Este corte metodológico tem por fundamento, também, a competência da União para estabelecer normas gerais de direito financeiro (art. 24 , I e $\S 1^{\circ}, \mathrm{CF} / 88$ ), que englobam as normas do direito dos gastos públicos.

A segunda limitação diz respeito aos regimes jurídicos do gasto público. Como será esclarecido a seguir, a partir da diversidade de organizações estatais e paraestatais, e dos diferentes tipos de operações que podem ser englobadas pelo conceito de despesa pública em sentido amplo, decorrem diversos regimes jurídicos do gasto público, os quais possuem um núcleo de princípios jurídico comum.

Não pretendo, neste trabalho, examinar em detalhe os diversos regimes jurídicos do gasto público, mas tão somente, traçar um panorama acerca destes regimes, estudando o núcleo comum de princípios jurídicos. 
Exclui-se, ainda, do escopo do trabalho as fases de elaboração, tramitação e aprovação do ciclo orçamentário. O orçamento, portanto, é um dado, uma variável exógena, independente e incontrolável para a análise que se segue.

Por fim, o presente trabalho não abrange o estudo do impacto das decisões judiciais no orçamento público em curso, apesar de reforçar a obrigatoriedade de pagamento de precatórios, conforme preconiza o art. 100 da CF/88.

\subsection{Estrutura do Trabalho}

O presente trabalho é dividido em 4 partes.

A primeira parte visa introduzir o leitor no tema da despesa pública, sendo composta por três capítulos.

No capítulo 2, discute-se o conceito de despesa pública e os componentes deste conceito. O gasto público é visto sob vários aspectos: em sentido amplo ou estrito, em sentido agregado ou individual. A despesa pública em sentido amplo também deverá abarcar o gasto tributário, uma vez que este submete-se aos princípios da legalidade, legitimidade e economicidade (art. 70, CF/88). Por fim, são apresentadas apenas as classificações da despesa úteis ao desenvolvimento dos estudos.

No capítulo 3, destaca-se o caráter instrumental da despesa pública em sentido amplo no contexto da implementação de políticas públicas. Neste capítulo, é abordado o "processo de concretização da despesa pública".

No capítulo 4, o gasto público é visto sob o ponto de vista de outras ciências extrajurídicas, tais como, a ciência econômica, a ciência da administração, a ciência política, e a contabilidade. Enfatiza-se a importância do estudo destes pontos de vista do fenômeno "despesa pública" para a interpretação das normas do direito dos gastos públicos.

Feita essa introdução, a segunda parte do trabalho busca construir as bases de um direito dos gastos públicos, sendo composta por 8 capítulos.

No capitulo 5, são estudados de forma simplificada os diferentes regimes jurídicos do gasto público.

No capítulo 6, são estudadas as fontes do direito dos gastos públicos, incluindo as fontes diretas, que encerram a norma jurídica e as indiretas ou de conhecimento, que ajudam a compreensão da norma, sem dar existências a elas.

No capitulo 7, traça-se um panorama geral sobre os princípios jurídicos do gasto público, ressaltando a sua importância na composição do sentido das regras 
jurídicas que disciplinam este instituto jurídico. O estudo detalhado de alguns destes princípios é deixado para os capítulos 8 a 11.

No capítulo 8, aborda-se a legalidade da despesa pública e os seus diferentes aspectos: legalidade orçamentária, legalidade global, legalidade procedimental e legalidade específica.

No capítulo 9, faz-se um estudo sobre o princípio da legitimidade da despesa pública, destacando-se o papel do princípio como veículo para que os demais valores, objetivos e princípios constitucionais se reflitam na disciplina do gasto público.

No capítulo 10, são discutidas as dimensões da avaliação de resultados da gestão pública (economicidade, eficiência, eficácia e efetividade) e é feita uma crítica ao conceito de qualidade dos gastos públicos.

No capítulo 11, é discutido o princípio da transparência da despesa pública, a sujeição ao controle e o dever de prestar contas.

No capítulo 12, são propostos alguns mecanismos e métodos para a interpretação e integração do direito dos gastos públicos.

$\mathrm{Na}$ terceira parte do trabalho, são discutidos alguns temas selecionados do direito dos gastos públicos: as despesas obrigatórias (capítulo 13), as transferências voluntárias (capítulo 14) e a destinação de recursos ao setor privado (capítulo 15).

A quarta parte discute a autonomia do direito dos gastos públicos em relação ao direito orçamentário e ao direito tributário (capítulo 16).

No capítulo 17, questiona-se se é possível falar num direito dos gastos públicos como um novo ramo do direito financeiro brasileiro.

No capítulo 18, são apresentadas as conclusões do trabalho.

No capítulo 19, constam as referências bibliográficas, sítios da internet, legislação e jurisprudência consultadas durante a realização da presente pesquisa.

Por fim, no Anexo I, são apresentadas algumas propostas de temas e assuntos relacionadas ao direito dos gastos públicos como sugestões de trabalhos futuros. 


\section{CONCLUSÕES}

Este estudo teve por objetivo identificar as regras e os princípios jurídicos que disciplinam a despesa pública no Brasil. Em especial, o estudo buscou identificar os critérios jurídicos para verificar a conformidade ou não de uma despesa com o ordenamento jurídico pátrio, com vistas a servir de subsídio ao gestor público e ao controle.

Neste mister, uma das primeiras tarefas foi apresentar um conceito de despesa pública ou gasto público adequado à realidade jurídico-financeira do país, considerando que um conceito muito amplo resultaria em diversos "regimes jurídicos do gasto público", pois as referidas normas não aplicar-se-iam igual e uniformemente em todo o escopo considerado. Por outro lado, um conceito muito restrito não iria explorar a completa dimensão do fenômeno jurídico-financeiro.

\section{Verificou-se a necessidade de ampliação do conceito de despesa pública} para abranger as despesas realizadas por entidades da administração indireta, entidades paraestatais e entidades de colaboração não sujeitas à legalidade orçamentária. Ademais, considerou-se a existência de normas que disciplinam o gasto público de forma agregada (legalidade agregada), impondo que a despesa pública também seja considerada sob este aspecto, não apenas a despesa singularmente considerada. Além disso, a ampliação da despesa pública é necessária para incluir operações, tais como, os benefícios fiscais e os benefícios creditícios, que se sujeitam aos princípios da administração pública e aos princípios da legalidade, legitimidade e economicidade, ainda que a disciplina seja escassa.

Para os propósitos deste estudo, a despesa pública não pode ser considerada um ato isolado. Há um processo de positivação ou concretização da despesa pública, que pode ser expresso num modelo de quatro estágios ou níveis de abstração. O nível mais elevado de abstração corresponde ao dos objetivos fundamentais da República, dos direitos fundamentais e das competências dos entes federados, dos órgãos e entidades públicas. Um segundo nível é o dos programas e políticas públicas, formulados(as) para atender estes objetivos fundamentais e concretizar os direitos fundamentais. Um terceiro nível é o dos atos e contratos administrativos, que operacionalizam as políticas e os programas públicos. E, por fim, um quarto nível corresponde ao nível das despesas públicas propriamente ditas, as quais estão condicionadas pelos atos e contratos administrativos. 
Este modelo revela o contexto em que a despesa pública está inserida, facilitando a análise da sua juridicidade. Entretanto, quanto maior a distância entre os níveis, mais difícil se torna esta comparação e análise. Do ponto de vista do controle financeiro exercido pelos Tribunais de Contas, uma verificação importante é em que medida a despesa pública busca atingir os objetivos e metas das políticas ou programas públicos.

A adoção de um conceito amplo de gasto público resulta numa diversidade de regimes jurídicos da despesa pública, a qual se deve, por um lado, pela diversidade de organismos estatais e paraestatais existentes no Brasil contemporâneo, bem como, pelas novas parcerias realizadas pela Administração Pública e o setor privado e o terceiro setor, e, por outro lado, pela diversidade de operações que podem ser enquadradas como despesa pública em sentido amplo além dos gastos diretos, tais como, as transferências voluntárias, a despesa fiscal (gasto tributário) e os benefícios creditícios.

Para identificar as regras e princípios que regulam o instituto da despesa pública, faz-se necessário identificar suas fontes formais e suas fontes de conhecimento. No Direito Brasileiro, as fontes formais são a Constituição Federal, as Leis Complementares, o Plano Plurianual, a Lei de Diretrizes Orçamentárias, a Lei Orçamentária Anual, as Leis Ordinárias, Normas Infralegais, os Tratados e Convenções Internacionais e as Súmulas Vinculantes do STF. Dentre as fontes de conhecimento, merecem destaque, no âmbito federal, as respostas às consultas realizadas ao TCU e os Pareceres do AGU.

Neste conjunto de fontes, a Constituição tem o papel de estabelecer os objetivos fundamentais da República, os direitos fundamentais, as competências dos entes federados e os princípios aplicáveis à despesa pública. As leis complementares em por função principal estabelecer normas gerais de direito financeiro (e consequentemente do direito dos gastos públicos) disciplinando as matérias que a Constituição expressamente requereu a complementação por esta espécie legislativa.

O plano plurianual, além de orientar a elaboração, orienta a aplicação/interpretação da lei orçamentária anual uma vez que define os macroobjetivos, diretrizes, os programas e as metas que devam ser atingidas no quadriênio. A Lei de Diretrizes Orçamentárias também exerce um papel de disciplinar os gastos públicos, ainda que de forma indireta, não se restringindo a orientar a elaboração da LOA. Sua vigência não se esgota com o encaminhamento do projeto de LOA ao Congresso Nacional. Ademais, a LDO também 
auxilia a interpretação/aplicação da LOA. A LOA, por sua vez, é a lei que estabelece as autorizações de gasto, para aquelas despesas/entidades sujeitas à legalidade orçamentária. As autorizações de gasto estão sujeitas à limitações/condicionamentos de caráter temporal, quantitativo e funcional. As leis ordinárias tem o papel de estabelecer os direitos subjetivos às prestações pecuniárias, de estabelecer as competências dos órgãos ou entidades públicas (servindo de base para a realização dos gastos) e de disciplinar as relações entre o Poder Público e os entes de colaboração, dentre outras funções. As normas infralegais servem para disciplinar a operacionalização da despesa pública, não podendo criar ou estabelecer direitos subjetivos à prestações pecuniárias. Os tratados e convenções internacionais podem gerar obrigações de gasto ao Poder Público, mas a eficácia destas obrigações condicionadas à deliberação do Congresso Nacional, nos termos do art. 49, I, da CF/88.

O núcleo comum de princípios jurídicos aplicáveis à despesa pública, em todas as suas manifestações, incluindo o gasto tributário e os benefícios creditícios, é composto por princípios de status constitucional, abrangendo os princípios fundamentais, os princípios constitucionais gerais, os princípios da administração pública e os princípios setoriais do direito dos gastos públicos. Dentre as funções dos princípios, destaca-se a função interpretativa e a função supletiva ou subsidiária. Os chamados "princípios orçamentários” também podem ser aplicáveis à despesa pública, ainda que estejam orientados principalmente à etapa de elaboração do orçamento público.

O princípio da legalidade aplicado à despesa pública não se restringe à legalidade orçamentária e pode ser observado sob diferentes planos ou aspectos: a legalidade orçamentária, a legalidade procedimental, a legalidade global e a legalidade específica. A legalidade orçamentária corresponde à observância das normas de natureza orçamentária, em especial, à observância das limitações quantitativas, temporais e finalísticas da autorização orçamentária para a realização da despesa contida na LOA. A legalidade procedimental corresponde à aderência ao procedimento legal previsto para a realização da despesa pública, que pode ser visto num sentido amplo, abrangendo o processo de contratação pública, quando este for aplicável. A legalidade agregada ou global corresponde à aderência às normas legais que disciplinam a despesa pública sob o ponto de vista agregado. Tais normas buscam proteger a equidade intergeracional e a sustentabilidade das finanças públicas e do crescimento econômico, ou seja, objetivos a longo prazo. A legalidade específica exige lei formal 
como condição necessária para o estabelecimento de direitos subjetivos a prestações pecuniárias estatais, mormente quando se confere um tratamento diferenciado entre os cidadãos.

O princípio da legitimidade incide sobre as políticas públicas, sobre os atos de gestão e, por consequência, sobre a despesa pública. À semelhança do princípio do devido processo legal, o princípio da legitimidade é um pólo para onde converge um feixe de princípios como, o da moralidade, do interesse público, da utilidade, da justiça e equidade, da isonomia, da razoabilidade, do consentimento coletivo, dentre outros. A legitimidade não se identifica com a legalidade, e a ilegalidade importa em ilegitimidade, mas não o contrário. Do ponto de vista do controle e do gestor público, a legalidade deve ser vista como uma presunção de legitimidade. Entretanto, é possível que a utilização da legitimidade como parâmetro de controle de constitucionalidade de leis que estabeleçam benefícios não razoáveis ou imorais a determinado grupo de pessoas e às custas do Tesouro Público. O princípio da legitimidade concede abertura para que valores, princípios, objetivos previstos na Constituição se reflitam também na gestão de recursos públicos e na despesa pública.

Os resultados do gasto público podem ser expressos por suas dimensões de desempenho: economicidade, eficácia, eficiência e efetividade. A economicidade está relacionada à aquisição dos insumos da ação administrativa nas melhores condições. A eficácia diz respeito ao grau de atingimento dos objetivos propostos. A eficiência diz respeito à relação entre os produtos e os insumos. A efetividade diz respeito ao impacto da ação governamental no público-alvo. Em razão disso, a economicidade é a que se aplica ao gasto público em sentido estrito e as demais se referem a todo o processo de concretização da despesa pública.

As dimensões de economicidade, eficácia e eficiência foram contempladas como princípios jurídicos explícitos pela Constituição Federal, o mesmo não acontecendo com a efetividade, possivelmente, em razão de esta estar mais sujeita a fatores exógenos à ação administrativa.

Todos os 4 E’s seriam aplicáveis às diversas etapas do ciclo da política pública. É na tomada de decisão que a eficiência deve prevalecer na escolha da melhor alternativa formulada. Na identificação do problema, deve-se realizar estudos que permitam que as intervenções estatais sejam mais efetivas. A implementação deverá se pautar pela eficácia, atingimento dos objetivos propostos, e pela economicidade na aquisição dos insumos. Por fim, a avaliação deverá revelar os 4 E’s da política pública, 
propiciando informações que retroalimentem o ciclo da política pública, de forma a corrigir os erros e formular novas alternativas que sejam mais eficientes e efetivas.

A expressão "qualidade do gasto público", embora seja usual e citada por diversos autores, no Brasil e no exterior, é ambígua e dispensável, podendo ser perfeitamente substituível pelos resultados da gestão pública ou por uma de suas dimensões: economicidade, eficiência, eficácia ou efetividade.

O princípio da transparência do gasto público é a projeção do princípio da transparência pública à despesa pública, sendo uma decorrência do princípio democrático e do Estado de Direito. Apresenta-se decomposto nos subprincípios da publicidade, motivação e participação popular, seguindo a visão de Wallace Paiva Martins Júnior.

A transparência do gasto público apresentou uma grande evolução desde o advento da Constituição Federal de 1988, com a Lei $\mathrm{n}^{\circ}$ 9.755/1998, com a Lei de Responsabilidade Fiscal, com a Lei da Transparência e a Lei de Acesso à Informação. Entretanto, ainda há um grande caminho a percorrer, proporcionando informação útil ao cidadão para que este influa, decisivamente, na administração pública. Os dados primários obtidos dos sistemas de informação da administração pública podem não ser úteis ao cidadão, podendo ser exigida análise, interpretação, consolidação ou tratamento dos dados para que estes sirvam ao propósito da cidadania. A avaliação dos resultados dos programas públicos e a sua divulgação é, neste contexto, essencial. Da mesma forma que a divulgação das informações pertinentes ao gasto tributário e os benefícios creditícios.

Uma das finalidades da transparência e seus subprincípios é justamente propiciar o exercício do controle, especialmente, o controle social. Um destes controles a posteriori impõe o dever de prestar contas e o dever de colaboração perante o Tribunal de Contas. A justificação da despesa é a motivação aplicada à despesa pública.

Os métodos de interpretação e integração do direito dos gastos públicos não diferem em sua essência dos métodos utilizados para a interpretação e integração da legislação comum. Entretanto, algumas particularidades na interpretação/integração do direito dos gastos públicos se justificam, tal como, em qualquer ramo do direito.

Desta forma, preconiza-se que a interpretação das normas seja feita considerando-se o princípio do bom emprego dos recursos públicos e dos demais princípios jurídicos e o contexto da despesa pública. No caso das dotações orçamentárias, propõe-se a interpretação segundo a lei de diretrizes orçamentárias, que 
define as classificações orçamentárias, a estrutura e organização da LOA e dispõe sobre as metas e prioridades da administração pública para o exercício financeiro em questão.

No caso de dotações que identifiquem entidades privadas sem fins lucrativos como beneficiárias, deve-se interpretá-las a luz do princípio da impessoalidade, desconsiderando tal identificação (Interpretação conforme a Constituição).

As normas que instituam direitos subjetivos a prestações pecuniárias devem ser interpretadas literal ou restritivamente, sob pena de violar o princípio da reserva legal (item 8.4).

No tocante à integração de lacunas, propõe-se, em atenção ao art. $4^{\circ}$ da LICC, é utilização hierarquizada dos princípios jurídicos na colmatação das lacunas, partindo-se dos princípios setoriais do gasto público, passando pelos princípios da administração pública, até chegar aos princípios constitucionais fundamentais. Desta forma, parte-se dos princípios menos abstratos para os princípios mais abstrados, procurando-se a solução, em último caso, nos princípios gerais de direito.

A Constituição Federal impõe a obrigatoriedade de aplicação de recursos mínimos em ações e serviços de saúde, na manutenção e desenvolvimento do ensino e a obrigatoriedade de inscrição orçamentária e pagamento dos precatórios judiciais. Tratase do "gasto constitucional” na visão de Regis Fernandes de Oliveira.

Da mesma forma, pode-se falar no "gasto legal", aquele que tem sua força obrigatória decorrente de lei. É o caso das despesas de pessoal e encargos sociais, o serviço da dívida pública, os benefícios da previdência social e os benefícios assistenciais (BPC e bolsa-família).

Em ambos os casos, os referidos gastos não estão sujeitos à limitação de empenho prevista no art. $9^{\circ}, \S 2^{\circ}$, da Lei de Responsabilidade Fiscal.

Seja no tocante ao gasto legal, quanto ao gasto constitucional, o que se pode concluir é que a fonte da obrigatoriedade não é o orçamento público. A obrigatoriedade advém da Constituição Federal e de leis, tais como as que estabelecem direitos subjetivos a prestações pecuniárias do Estado, o que constitui mais um fator no sentido de desvincular a disciplina do gasto público do direito orçamentário.

As transferências voluntárias são despesas públicas em sentido estrito, podendo consistir de transferências correntes ou de capital. São instrumentos de descentralização negociada de recursos financeiros e encargos para os entes subnacionais. A disciplina jurídica das transferências voluntárias abarca desde normas 
constitucionais, tais como, a que estabelece a vedação de transferências voluntárias para pagamento de despesas de pessoal, ativo e inativo, dos entes subnacionais, até normas infralegais, que disciplinam de forma mais detalhada a concessão, celebração, execução, acompanhamento e prestação de contas dos recursos transferidos.

A LRF e a LDO tem importante papel na disciplina das transferências voluntárias. A LRF define o conceito de transferências voluntárias e impõe requisitos para o repasse, dentre os quais, aqueles estabelecidos pela LDO do referido exercício financeiro. Além disso, na LRF, a suspensão do recebimento de transferências voluntárias é prevista como principal "sanção institucional” para o descumprimento dos preceitos contidos na referida lei.

Merecem destaque, no âmbito da disciplina jurídica das transferências voluntárias, os seguintes pontos:

a) a não obrigatoriedade dos repasses voluntários;

b) a exigência de ganhos de eficiência na implementação do objeto, em decorrência da descentralização financeira;

c) a exigência de acompanhamento do órgão repassador, que permanece com o dever de implementar as ações descentralizadas, cabendo a ele assumir execução do objeto, quando for o caso;

d) as transferências só são cabíveis no caso de objeto de interesse recíproco dos entes federados, evidenciado pelas competências legais ou constitucionais do concedente e do convenente;

e) os objetos das transferências voluntárias devem concretizar os objetivos e metas da ação orçamentária descentralizada;

f) os recursos financeiros transferidos não podem ser utilizados em outra finalidade que não a pactuada.

A destinação de recursos ao setor privado não se confunde com as transferências voluntárias, uma vez que, segundo o art. 25, caput, da LRF, estas estão restritas aos repasses entre entes federados. A destinação de recursos ao setor privado merece um tratamento jurídico diferenciado das transferências voluntárias, especialmente, com o advento da Lei de Responsabilidade Fiscal (arts. 25 e 26). Esta diferenciação deve ser ressaltada uma vez que as normas infralegais costumam disciplinar de forma semelhante os repasses para os entes federados e os repasses para as entidades sem fins lucrativos, por meio de convênios ou contratos de repasse. 
As parcerias realizadas pelo poder público com as entidades do setor privado, com ou sem fins lucrativos, com vistas à prestação assistencial no Sistema Único de Saúde (SUS), tem um tratamento especial, dentre as demais parcerias, já encontrando fundamento na Constituição Federal e na Lei $n^{\circ}$ 8.080/1990. O art. 16 da Lei $n^{\circ}$ 4.320/1964 também oferece fundamento legal para a concessão de subvenções sociais às entidades prestadoras de serviços de assistência social e educacional.

A celebração de convênios entre o poder público com Organizações NãoGovernamentais, com repasse de recursos públicos, exige lei formal que autorize e discipline tal transferência, sob pena de violação do princípio da legalidade da administração pública, na sua vertente reserva legal.

Nada obstante, à semelhança do que ocorre com os contratos administrativos, com os termos de parceria, com os contratos de gestão, o princípio da legalidade impõe ainda uma disciplina mínima do convênio em questão que abarque a seleção do parceiro e seus requisitos, as cláusulas necessárias ao instrumento de convênio, a execução do convênio, a forma como devem ser feitos os repasses, o controle e a prestação de contas.

O direito dos gastos públicos não pode ser visto como um subconjunto do direito orçamentário, uma vez que o orçamento constitui apenas um dos condicionantes do gasto público, ainda assim, somente dos gastos sujeitos à legalidade orçamentária. $\mathrm{O}$ fenômeno da desorçamentação, a existência de normas de caráter permanente que disciplinam a despesa pública, a possibilidade de alteração e retificação do orçamento pelo poder executivo e a margem de discricionariedade concedida pelas dotações orçamentárias com títulos genéricos relativizam a importância da lei orçamentária na disciplina do gasto público.

Só faz sentido pensar num direito dos gastos públicos, quando se adota a despesa na sua concepção ampla, abrangendo o processo de concretização da despesa pública. Entretanto, ao abarcar os atos geradores da despesa e as políticas públicas, o direito dos gastos públicos precisa recorrer aos princípios emprestados do direito constitucional e do direito administrativo, fazendo mais sentido falar num direito da gestão pública ou num direito das políticas públicas, o que extrapolaria o escopo do direito financeiro. 


\section{REFERÊNCIAS}

\subsection{Bibliografia}

ABAD, Mariano et al. Notas de Introducción al Derecho Financiero. Madrid: Tecnos, 1992. 277p.

ACKERMAN, Susan Rose. La Corrupción y Los Gobiernos - causas, consecuencias y reforma. Trad. Alfonso Colodrón Gómez. Madrid: Siglo XXI, 2001. 366 p.

AFONSO, José Roberto Rodrigues. Memória da Assembléia Nacional Constituinte de 1987/88: as Finanças. Públicas. Revista do BNDES, v.6, p.21 - 48, junho/1999.

AGUIAR, Afonso Gomes. Direito Financeiro: lei $n^{\circ} 4.320$ - comentada ao alcance de todos. $3^{\mathrm{a}}$. ed. Belo Horizonte: Fórum, 2004. 468p.

ALBUQUERQUE, Claudiano Manuel de; MEDEIROS, Márcio Bastos; FEIJÓ DA SILVA, Paulo Henrique. Gestão de Finanças Públicas: fundamentos e prática de planejamento, orçamento e administração financeira com responsabilidade fiscal. Brasília: Paulo Henrique Feijó da Silva Editor, 2006. 483 p.

ALMEIDA, Francisco Carlos Ribeiro de. A renúncia de receita como fonte alternativa de recursos orçamentários. Revista do Tribunal de Contas da União. Brasília, v. 32, $\mathrm{n}^{\circ} 88$, abr/jun. 2001.

ALMEIDA, Francisco Carlos Ribeiro de. Introdução à Auditoria. Apostila do Curso de Formação AFCE-CE. Brasília: Instituto Serzedello Corrêa/TCU, 2000.

ALMEIDA, Marcelo Cavalcanti. Auditoria - um curso moderno e completo. São Paulo: Atlas, 1996. 417 p.

ALMEIDA JR., Mansueto F. de. Adeus Déficit Nominal Zero. Disponível em http://mansueto.wordpress.com. Acesso em 1.11.2013.

ALVES NETO, José. Princípios Orçamentários - uma análise no contexto das constituições e leis orçamentárias federais. 2006. 53f. Monografia (Especialização em Contabilidade e Orçamento) - Universidade de Brasília, Brasília, 2006.

ARNIN, Hans Herbert von. Wirtschaftlichkeit als Rechtsprinzip. Berlin: Duncker u. Humbolt, 1988. 122 p.

ASSONI FILHO, Sérgio. Transparência Fiscal e Democracia. Porto Alegre: Núria Fabris, 2009. 268 p.

ÁVILA, Humberto. Teoria dos Princípios - da definição à aplicação dos princípios jurídicos. $8^{\mathrm{a}}$. ed. São Paulo: Malheiros, 2008. 182 p. 
AZZONE, Giovanni. Controllo di gestione nelle amministrazioni pubbliche decisioni e accountability per ministeri, enti locali e università. Milano: Etas, 2008. $326 \mathrm{p}$.

BAHL, Roy. Intergovernmental Transfers in Developing and Transition Countries: principles and practice. World Bank, 1999. Disponível a partir de: http://www.worldbank.org. Acesso em 1/1/2012.

BALEEIRO, Aliomar. Uma introdução à ciência das finanças. $14^{\text {a }}$. ed. Rio de Janeiro: Forense, 1995. 493 p.

BAZILLI, Roberto Ribeiro; MIRANDA, Sandra Julien. Licitação à luz do direito positivo. São Paulo: Malheiros, 1999. 316 p.

BENTO, Vitor. A desorçamentação das despesas públicas. Revista do Tribunal de Contas. Lisboa, $\mathrm{n}^{\circ}$ 34, p. 23-35, jul./dez. 2000.

BEZERRA, Ricardo Alfredo Ribeiro. Incentivos para a promoção da qualidade do gasto público - fortalecendo o vínculo entre recursos e resultados. Brasília: SOF/MPOG, 2008. Disponível em http://www.orcamentofederal.gov.br. Acesso em $1 / 11 / 2013$.

BISHOP, Matthew. Economics: an A-Z guide. London: The Economist, 2003. 340 p.

BORGES, Alice Gonzalez. Serviços sociais autónomos - natureza jurídica. In: MODESTO, Paulo (org). Nova Organização Administrativa Brasileira, 2a . ed. Belo Horizonte: Fórum, 2010. p. 259-273.

BORJA, Rodrigo. Enciclopedia de La Política. 2a . ed. México: Fondo de Cultura Económica, 1998. 1040p.

BORJAS, Maria de la Luz Mijangos. Conceptos generales del derecho financiero. In: BONFAZ, Chapoy; BEATRIZ, Dolores (org). Panorama de derecho mexicano derecho financiero. Mexico: Mc Graw Hill, 1997. p. 1-7.

BOTE, Valentín et al. Transparencia Pública. Madrid: Lid Editorial Empresarial, 2007. $186 \mathrm{p}$.

BOUVIER, Michel; ESCLASSAN, Marie-Christine; LASSALE, Jean-Pierre. Finances Publiques. $8^{\mathrm{a}}$. ed. Paris: LGDJ-EJA, 2006. 882 p.

Brasil. Congresso Nacional. Comissão Mista de Planos, Orçamentos Públicos e Fiscalização. Manual de Elaboração e Apresentação de Emendas - Orçamento da União para 2013. Brasília: COFF/CD e CONORF/SF, 2012. 156 p. 
BRASIL. Ministério do Orçamento, Planejamento e Gestão. Manual da Legislação Federal sobre Convênios da União - orientações aos municípios. Brasília: MPOG, 2009. Disponível em: http://www.convenios.gov.br. Acesso em 1/9/2010.

BRASIL. Ministério do Orçamento, Planejamento e Gestão. Secretaria de Orçamento Federal. Manual Técnico de Orçamento - MTO 2011. Brasília: MPOG, 2010. 189 p. BRASIL. Ministério do Orçamento, Planejamento e Gestão. Secretaria de Orçamento Federal. Manual Técnico de Orçamento - MTO 2014. Brasília: MPOG, 2013. 183 p. BRASIL. Ministério do Orçamento, Planejamento e Gestão. Secretaria de Planejamento e Investimentos Estratégicos. Orientações para elaboração do Plano Plurianual 2012-2015. Brasília: MP, 2011. 72 p.

BRASIL. Ministério da Fazenda. Secretaria do Tesouro Nacional. Manual Técnico de Contabilidade Aplicada ao Setor Público: Aplicado à União, Estados, Distrito Federal e Municípios a partir da elaboração e execução da lei orçamentária de 2009, vol. II. Brasília: STN, 2008. 120p.

BRASIL. Tribunal de Contas da União. Relatório e Parecer Prévio sobre as Contas da República - exercício de 2009. Brasília: TCU, 2010. 463 p.

BRUNET, Julio Francisco Gregory; BERTE, Ana Maria de Aveline e BORGES, Clayton Brito. Estudo Comparativo das Despesas Públicas dos Estados Brasileiros: um índice de qualidade do gasto público. Brasília: ESAF, 2007. Monografia premiada com o terceiro lugar no XII Prêmio Tesouro Nacional - 2007. Qualidade do Gasto Público. Porto Alegre.

BUGARIN, Paulo Soares. O princípio constitucional da economicidade na jurisprudência do Tribunal de Contas da União. Belo Horizonte: Fórum, 2004. 237 p.

CARNEIRO NETO, Durval. Os conselhos de fiscalização profissional: uma trajetória em busca de sua identidade jurídica. In: MODESTO, Paulo (org). Nova Organização Administrativa Brasileira. 2a . ed. Belo Horizonte: Fórum, 2010. p. 275-320

Processo, jurisdição e ônus da prova no direito administrativo - um estudo crítico sobre o dogma da presunção de legitimidade. Salvador: Juspodium, 2008. 395 p.

CARRAZZA, Roque Antônio. Curso de Direito Constitucional Tributário. 21 a ed. São Paulo: Malheiros, 2005. 946 p. 
CARVALHO, André Castro. Infraestrutura sob uma perspectiva pública: instrumentos para o seu desenvolvimento. 2013. $549 \mathrm{f}$. Tese (Doutorado em Direito) - Faculdade de Direito, Universidade de São Paulo, São Paulo, 2013.

Vinculação de Receitas Públicas. São Paulo: Quartier Latin, 2010. $291 \mathrm{p}$.

CARValho FILHO, José dos Santos. Manual de Direito Administrativo. 15a . ed. Rio de Janeiro: Lumen Juris, 2006. 985 p.

CASSIOLATO, Martha; GUERESI, Simone. Como elaborar Modelo Lógico roteiro para formular programas e organizar avaliação. Brasília: IPEA, 2010. 35 p.

CATARINO, João Ricardo. Princípios de Finanças Públicas. Coimbra: Almedina, 2011. $272 \mathrm{p}$.

CHAGAS, Anderson Erlani Oliveira de. Avaliação de Desempenho da Gestão da Dívida Pública, com Enfoque na Atuação da Secretaria Federal de Controle Interno (SFC). 2010. 31f. Monografia (Especialização em Orçamento Público) Instituto Serzedello Correa, Brasília, 2010.

CHAVES, Francisco Eduardo Carrilho. Controle Externo da Gestão Pública - a fiscalização pelo legislativo e pelos Tribunais de Contas - teoria e jurisprudência. Niterói: Impetus, 2007. 355p.

CONTI, José Maurício. Direito Financeiro na Constituição de 1988. São Paulo: Oliveira Mendes, 1998. 131 p.

Federalismo Fiscal e Fundos de Participação. São Paulo: Juarez de Oliveira, 2001. 160 p.

CONTI, José Maurício; SCAFF, Fernando Facury (org). Orçamentos Públicos e Direito Financeiro. São Paulo: RT, 2011. 1342p.

CONTI, José Mauricio (org). Orçamentos Públicos: A lei 4.320 Comentada. São Paulo: RT, 2008. 347 p.

CORREIA NETO, Celso de Barros. Orçamento público: uma visão analítica. Brasília: Secretaria de Orçamento Federal, 2008. Prêmio SOF de Monografias. Disponível a partir de <http://www.esaf.fazenda.gov.br/>. Acesso em: 10/09/2013.

DALLARI, Adilson Abreu. Orçamento Impositivo. In: CONTI, José Maurício; SCAFF, Fernando Facury (org). Orçamentos Públicos e Direito Financeiro. São Paulo: RT, 2011. P. 309-327.

DECOMAIN, Pedro Roberto. Tribunais de Contas no Brasil. São Paulo: Dialética, 2006. 
DEUBEL, André-Noël Roth. Políticas Públicas - formulación, implementación y evaluación. Bogotá: Ediciones Aurora, 2012. 218 p.

DIAS, Fernando Álvares Correia. O controle institucional das despesas com pessoal. Brasília: Senado Federal, 2009. 34 p.

DIAS, Reinaldo; MATOS, Fernanda. Políticas Públicas - principios, propósitos e processos. São Paulo: Atlas, 2012. 221 p.

DINIZ, Maria Helena. Compêndio de Introdução à Ciência do Direito. São Paulo: Saraiva, 2003. 535 p.

DI PIETRO, Maria Sylvia Zanella. Parcerias na Administração Pública: concessão, permissão, franquia, terceirização, parceria público-privada e outras formas. $5^{\mathrm{a}}$. ed. São Paulo: Atlas, 2005. 443 p.

DI PIETRO, Maria Sylvia Zanella. Direito Administrativo. $14^{\text {a }}$. ed. São Paulo: Atlas, 2002. $695 \mathrm{p}$.

EPPING, Volker; LENZ, Sebastian; LEYDECKER, Philipp. Grundrechte. $3^{\mathrm{a}}$. ed. Berlin-Heidelberg: Springer, 2007. 450 p.

FERNANDES, Jorge Ulisses Jacoby. Tribunais de Contas do Brasil - jurisdição e competência. Belo Horizonte: Ed. Fórum, 2003. 890 p.

FERnANDEZ, Luis Omar; D’AGOSTINO, Hernán Miguel. Manual de Finanzas Públicas. Buenos Aires: La Ley, 2007. 413 p.

FILELINI, Alfredo. Economia do Setor Público. São Paulo: Atlas, 2000. 202 p.

FONROUGE, Carlos M. Giuliani. Derecho Financiero, vol. I. 6 $6^{\text {a }}$ ed. Buenos Aires: Depalma, 1997. $651 \mathrm{p}$.

FMI. El gasto público improductivo: un enfoque pragmático para el análisis de las medidas de política. Washington: Departamento de Finanzas Públicas, 1996. 48 p.

FRANCO, Antônio Luciano de Souza. Finanças Públicas e Direito Financeiro, vol. I. 4a. ed. Coimbra: Almedina, 2002. 495 p.

FREITAS, Juarez. A interpretação sistemática do direito. $4^{\text {a }}$. ed. São Paulo: Malheiros, 2004. 309 p.

FREITAS, Urandi Roberto Paiva. CASTRO NETO, Armando Affonso de. LÔU, Isaac Coimbra. Relação entre Gastos Públicos e Crescimento Econômico - uma análise com dados em painel para o Nordeste. Conj.\& Planej., Salvador, ${ }^{\circ} 162$, p. 50-57, jan/mar. 2009. Disponível em http://www.sei.ba.gov.br. Acesso em 10/10/2013.

FUCS, José. As mágicas contábeis do Governo para tentar esconder o desequilíbrio das contas. Revista Época, São Paulo, 9/11/2013. Lições de Economia, p 50-55. 
FURTADO, José de Ribamar Caldas. O controle de legitimidade do gasto público. Biblioteca Digital Fórum de Contratação e Gestão Pública, Belo Horizonte, ano 5, n. 54, jun. 2006. Disponível a partir de http://www.editoraforum.com.br. Acesso em: $3 / 3 / 2010$.

GARCÍA, José Pascual. Régimen Jurídico del Gasto Público - presupuestación, ejecución y control. $4^{\text {a }}$. ed. Madrid: Boletín Oficial del Estado, 2005. 917 p.

GIACOMONI, James. Orçamento Público, 13 ${ }^{\mathrm{a}}$. ed. São Paulo: Atlas, 2005. 311 p. - Receitas Vinculadas, Despesas Obrigatórias e Rigidez Orçamentária. In: CONTI, José Maurício; SCAFF, Fernando Facury (org). Orçamentos Públicos e Direito Financeiro. São Paulo: RT, 2011. p. 329-356.

GIAMBIAGI, Fábio; ALÉM, Ana Cláudia. Finanças Públicas - teoria e prática no Brasil. 2a . ed. Rio de Janeiro: Campus, 2000. 475 p.

GOMES, Emerson Cesar da Silva. A disciplina jurídica das transferências voluntárias. In: CONTI, José Maurício; SCAFF, Fernando Facury (org). Orçamentos Públicos e Direito Financeiro. São Paulo: RT, 2011. p. 803-820.

Fundamentos das transferências intergovernamentais.

Jus Navigandi, Teresina, ano 12, n. 1580, 29 out. 2007. Disponível em: http://jus.uol.com.br/revista/texto/10589. Acesso em: 30 nov. 2010.

O Financiamento da Educação Básica no Brasil. In: ABMP; TODOS PELA EDUCAÇÃO (org). Justiça pela Qualidade na Educação. São Paulo: Saraiva, 2013. p. 266-287.

Responsabilidade Financeira - uma teoria sobre a responsabilidade no âmbito nos tribunais de contas. Porto Alegre: Núria Fábris, 2012. 344p.

USA. Government Accountability Office. Tax Expenditures: background and evaluation criteria and questions. Washington: GAO, 2012. 35 p.

GRAU, Eros Roberto. Ensaio e Discurso sobre a Interpretação/Aplicação do Direito. $2^{\text {a }}$. ed. São Paulo: Malheiros, 2003. 230 p.

GRUBER, Jonathan. Finanças Públicas e Política Pública. Trad. Antônio Zoratto Sanvincente. $2^{\mathrm{a}}$. ed. Rio de Janeiro: LTC, 2009. 444p.

HarguindéguY, Jean-Baptiste. Análisis de Políticas Públicas. Madrid: Tecnos, 2013. 259 p. 
HENRIQUES, Élcio Fiori. Os Benefícios Fiscais no Direito Financeiro e Orçamentário: o gasto tributário no direito brasileiro. São Paulo: Quartier Latin, 2010. 284 p.

HOLMES, Stephen; SUNSTEIN, Cass R. The cost of rights - why liberty depends on taxes. New York: W.W. Norton \& Company, 1999. 255 p.

HOWLETT, Michael. Designing Public Policies - principles and instruments. New York: Routledge, 2011. 160 p.

HOWLETT, Michael; RAMESH, M.; PERL, Anthony. Política pública: seus ciclos e subsistemas - uma abordagem integradora. Trad. Francisco G. Heidemann. Rio de Janeiro: Elsevier, 2013. 238 p.

JUSTEN FILHO, Marçal. Comentários à Lei de Licitações e Contratos Administrativos. 11ª . ed. São Paulo: Dialética, 2005. 666 p.

KELSEN, Hans. Teoria Pura do Direito. Trad. João Baptista Machado. 6a. ed. São Paulo: Martins Fontes, 1999. 427 p.

KENNEDY, Peter E. Macroeconomia em contexto: uma abordagem real e aplicada ao mundo econômico. São Paulo: Saraiva, 2011. 417 p.

LAPATZA, José Juan Ferreiro. Derecho Financiero, vol. I. Madrid: Marcial Pons Ediciones Juridicas y Sociales, 2004. 333 p.

LEITE, Harrison Ferreira. Autoridade da lei orçamentária. Porto Alegre: Livraria do Advogado, 2011.276 p.

LUCA, Gianni de. Contabilità di Stato e degli Enti Pubblici. 18 ${ }^{\text {a }}$. ed. Napoli: Simone, 2008.

MACHADO, Hugo de Brito. Curso de Direito Tributário. 26a . ed. São Paulo: Malheiros, 2005. 493 p.

MAGAlHÃES, Carla Sofia Dantas. Regime Jurídico da Despesa Pública: do direito da despesa ao direito à despesa. 2011. 137f. Dissertação (Mestrado em Direito) Escola de Direito, Universidade do Minho, Minho, 2011.

MAIA, Alexandre et al. A importância da melhoria da qualidade do gasto público no Brasil - propostas práticas para alcançar este objetivo. 2009. Disponível em http://www.consad.org.br. Acesso em 1/11/2013.

MANDL, Ulrike; DIERX, Adriaan; ILZKOVITZ, Fabienne. The effectiveness and efficiency of public spending. Brussels: European Comission, 2008. 32 p. 
MARTÍN, Francisco Alvira; LÓPEZ, José Garcia; LOBO, Luisa Delgado. Sociedad, Impuestos y Gasto Público - la perspectiva del contribuyente. Madrid: CIS, 2000. $236 \mathrm{p}$.

MARTINS, Cláudio. Compêndio de Finanças Públicas. 2a . ed. São Paulo: J. Bushatsky, 1976. 236 p.

MARTINS, Guilherme d'Oliveira; MARTINS, Guilherme Waldemar d'Oliveira; MARTINS, Maria d'Oliveira. Lei de Enquadramento Orçamental - anotada e comentada. $2^{\mathrm{a}}$. ed. Coimbra: Almedina, 2009. 381p.

MARTINS, Maria d'Oliveira. Lições de Finanças Públicas e Direito Financeiro. 2a . ed. Coimbra: Almedina, 2012. 276 p.

MARTINS JUNIOR, Wallace Paiva. Transparência administrativa - publicação, motivação e participação popular. São Paulo: Saraiva, 2004. 393p.

MAURER, Hartmut. Direito Administrativo Geral. Trad. Luís Afonso Heck. Barueri: Manole, 2006. 955 p.

MEIRELlES, Hely Lopes. Direito Administrativo Brasileiro. 19a . São Paulo: Malheiros, 1994. 671 p.

MELLADO, Luis Miguel Téllez. Gestión de Control Público. Santiago: Puntolex, 2007. 396 p.

MELlO, Celso Antônio Bandeira de. Curso de Direito Administrativo. 18 a ed. São Paulo: Malheiros, 2005. 973 p.

MENDES, Marcos José. Federalismo Fiscal. BIDERMAN, Ciro; ARVATE, Paulo (org). Economia do Setor Público no Brasil. Rio de Janeiro: Elsevier, 2004. pp. 421 461.

MENDES, Marcos (org.). Gasto Público Eficiente - 91 propostas para o desenvolvimento do Brasil. Rio de Janeiro: Top Books, 2006. 475 p.

MENDES, Marcos José. Sistema Orçamentário Brasileiro: planejamento, equilíbrio fiscal e qualidade do gasto público. Brasília: Consultoria Legislativa do Senado Federal, 2009. Disponível a partir de http://www.esaf.fazenda.gov.br/. Acesso em $1 / 10 / 2013$.

MENDES, Renato Geraldo. O proceso de contratação pública - fases, etapas e atos. Curitiba: Zenite, 2012.412p.

MILESKI, Hélio Saul. O controle da gestão pública. São Paulo: RT, 2003.

MODESTO, Paulo. Legalidade e autovinculação da Administração Pública pressupostos conceituais do contrato de autonomía no anteprojeto da nova lei de 
organização administrativa. In: MODESTO, Paulo (org). Nova Organização Administrativa Brasileira, 2a . ed. Belo Horizonte: Fórum, 2010. p. 115-174.

MONTORO, André Franco. Introdução À Ciência Do Direito. $28^{a}$ ed. São Paulo: RT, 2009. $686 \mathrm{p}$.

MORATAL, Gérman Orón. La configuración constitucional del gasto público. Madrid: Editorial Tecnos, 1995. 138 p.

MORLACCHI, Annamaria. Scienza delle Finanze e Diritto Finanziario. XX ed. Napoli: Simone, 2010. 426 p.

MOTA, Francisco Glauber Lima. Contabilidade Aplicada à Administração Pública, $6^{\mathrm{a}}$. ed. Brasília: Vestcon, 2003. 592 p.

MUSGRAVE, Richard A.; MUSGRAVE, Peggy B. Public Finance in Theory and Practice. $5^{\mathrm{a}}$. ed. New York: McGraw-Hill, 1989. 611p.

NAGEL, José. Normas gerais sobre Fiscalização e Julgamento a Cargo do TCU. Revista do Tribunal de Contas da União, Brasília, n 74, p. 31-48, out/dez. 1997.

NUNES, Selene Peres Peres. A geração da despesa. NUNES, Selene Peres Peres (org). Manual Básico de Treinamento para Municípios - programa nacional de treinamento). $2^{\mathrm{a}}$ edição. Ministério do Planejamento, Orçamento e Gestão: Brasília, 2002. pp. $117-144$.

OLIVEIRA, Regis Fernandes de. Curso de Direito Financeiro. São Paulo: RT, 2006. $600 \mathrm{p}$.

ORTEGÓN, Edgar; PACHECO, Juan Francisco; ROURA, Horácio. Metodología General de Identificación, preparación y evaluación de proyectos de inversión pública. Santiago: CEPAL/ILPES, 2005. 243 p.

OTERO, Paulo. Legalidade e Administração Pública - o sentido da vinculação administrativa à juridicidade. Lisboa: Almedina, 2003. 1102p.

PEREIRA, Paulo Trigo et al. Economia e Finanças Públicas. 4a . ed. Lisboa: Escolar, 2012. 579p.

PEREIRA, Paulo Trigo. Portugal - dívida pública e défice democrático. Lisboa: FFMS, 2012. 127 p.

PEREIRA, Thiago Rabelo; SIMÕES, Adriano; CARVALHAL, André. Mensurando o Resultado Fiscal das Operações de Empréstimo do Tesouro ao BNDES - custo ou ganho líquido esperado para a União? Rio de Janeiro: IPEA, 2011. 43 p.

PEROGORDO, Juan José Bayona de; ROCH, María Teresa Soler. Derecho Financiero, 2a ${ }^{a}$ ed., vol. 1. Alicante: Librería Compas, 1989. 717 p. 
PEROGORDO, José Juan Bayona de. El derecho de los gastos públicos. Madrid: Instituto de Estudios Fiscales, 1991. 353 p.

PIRES, João Batista Fortes de Souza. Contabilidade pública - orçamento público lei de responsabilidade fiscal - teoria e prática. $6^{\mathrm{a}}$. ed. Brasília: Franco e Fortes, 2001 .

PROCOPIUCK, Mário. Políticas Públicas e Fundamentos da Administração Pública - análise e avaliação, governança e redes de políticas, administração judiciária. São Paulo: Atlas, 2013. 355 p.

RAMOS, Giselda Gondin. Princípios Jurídicos. Belo Horizonte: Ed. Fórum, 2012. $611 \mathrm{p}$.

RAYA, Francisco José Carrera. Manual de Derecho Financiero, vol. I (derecho financiero y teoría de los ingresos públicos). Madrid: Tecnos, 1994. 278 p.

Manual de Derecho Financiero, vol. III (derecho presupuestario). Madrid: Tecnos, 1995. 180 p.

REIS, Heraldo da Costa. Subvenções, contribuições e auxílios. Revista de Administração Municipal - Municípios, Rio de Janeiro, v. 54, n. 268, p. 56, out./dez. 2008.

REZENDE, Fernando; CUNHA, Armando. Disciplina Fiscal e Qualidade do Gasto Público - fundamentos da reforma orçamentária. Rio de Janeiro: FGV, 2005. 156p.

ROCHA, Fabiana; GIUBERTI, Ana Carolina. Composição do gasto público e crescimento econômico: uma avaliação macroeconômica da qualidade dos gastos dos Estados brasileiros. Econ. Apl., Ribeirão Preto, v. 11, n 4, Dez/2007. Disponível em http://www.scielo.br. Acesso em 1/10/2013

ROCHA, Joaquim Freitas da. Sustentabilidade e Finanças Públicas Responsáveis urgência de um direito financiero equigeracional. In: Estudos em homenagem ao Professor José Joaquim Gomes Canotilho, vol. I. Coimbra: Coimbra Editora, 2012. p. 619-632.

RÖHL, Klaus F.; RÖHL, Hans Christian. Allgemeine Rechtslehre. $3^{\text {a }}$. ed. Köhl: Carl Heymanns Verlag, 2008. 697 p.

ROLDÁN, Luis Martínez; SUÁREZ, Jesús A. Fernández. Curso de Teoría del Derecho. 4ª . ed. Barcelona: Ariel Derecho, 2006. 230 p.

RÜTHERS, Bernd. Rechtstheorie. 4a . ed. München: C.H. Beck, 2008. 618 p. 
SANCHEZ, Yolanda Gómes. El tribunal de cuentas - el control económicofinanciero externo en el ordenamiento constitucional español. Madrid: Marcial Pons, 2001

SARLET, Ingo Wolfgang; TIMM, Luciano Benetti (org.). Direitos Fundamentais orçamento e reserva do possível. $2^{\mathrm{a}}$. ed. Porto Alegre: Livraria do Advogado, 2010. $412 \mathrm{p}$.

SCHICK, Allen. Off-budget expenditure: an economic and political framework. OECD Journal on Budgeting, $\mathrm{n}^{\circ}$ 3, vol. 7, p. 1-32, 2007. Disponível em http://www.oecd.org/dataoecd/42/28/43411741.pdf. Acesso em 1/6/2012.

The Federal Budget - politics, policy, process. $3^{\mathrm{a}}$. ed. Washington:

Brookings Institution Press, 2007. 333 p.

SCPOGANIZ, Rubens. Poder de Compra Estatal - requisitos e estratégias para o desenvolvimento e qualificação de fornecedores de pequeno porte. $2003.90 \mathrm{f}$. Dissertação (Mestrado em Engenharia de Produção) - Universidade Federal de Santa Catarina, Florianópolis, 2003.

SERRA, José. A Constituição e o Gasto Público. In: Planejamento e Políticas Públicas, Rio de Janeiro, n 21, Jun/1989. p. 93-106.

SILVA, Lino Martins da. Contabilidade Governamental - um enfoque administrativo. $7^{\text {a }}$. ed. São Paulo: Atlas, 2004.

SILVA, José Afonso da. Aplicabilidade das Normas Constitucionais. 6 ${ }^{\text {a }}$ ed. São Paulo; Malheiros, 2004. 263 p.

Comentário Contextual à Constituição. Malheiros: São

Paulo, 2005.

Orçamento-programa no Brasil. São Paulo: RT, 1973. 380p.

SILVA JR. Jocelino Mendes da. A Implementação da Lei Complementar $\mathbf{n}^{\circ}$ 131/2009 (Lei da Transparência) pelos Estados do Norte do Brasil - uma análise da sua eficácia como instrumento de controle social e de cidadania. 2010. 58f. Monografia (Especialização em Direito Público) - Universidade Anhanguera - Uniderp, Palmas, 2010.

SOARES, Guido Fernando Silva. Curso de Direito Internacional Público, vol. 1. São Paulo: Atlas, 2002. 437 p.

SOUZA, Ruy de. Ciência das Finanças. Belo Horizonte: Faculdade de Direito da Universidade de Minas Gerais, 1953. 
STAENDER, Klaus. Lexikon der öffentlichen Finanzwirtschaft. $6^{\text {a }}$. ed. Heidelberg: C.F. Müller, 2004. 507 p.

STIGLITZ, Joseph E. Economics of the public sector. 3a. ed. New York: W.W. Norton\& Company, 2000. 823 p.

SUNFELD, Carlos Ari. Fundamentos de Direito Público. $4^{\text {a }}$. ed. São Paulo: Malheiros, 2006. 186 p.

TALLAR, Carlos Hanssen. La función jurisdiccional de la Contraloría General de la República - el juicio de cuentas. Santiago: LexisNexis, 2007. 220p.

TANZI, Vito. The Quality of Public Sector. 1999. Disponível em http://www.imf.org. Acesso em 8/8/2012.

TAVARES, José; MAGALHÃES, Lídio de. Tribunal de Contas - legislação anotada com índice remissivo. Coimbra: Almedina, 1990. 351p.

TEIXEIRA, Ivandi Silva; TEIXEIRA, Regina Cleide. SOUSA, Rejane Assunção. Qualidade dos serviços: um diferencial competitivo. 2010. Disponível em http://www.aebd.br. Acesso em 1/11/2013.

TEMER, Michel. Elementos de Direito Constitucional. 14a. ed. São Paulo: Malheiros, 1998. 212 p.

TORRES, Ricardo Lobo. Curso de Direito Financeiro e Tributário. $3^{\mathrm{a}}$. ed. Rio de Janeiro: Renovar, 1996. 357 p.

Tratado de Direito Constitucional Financeiro e

Tributário. vol. V (o orçamento na constituição). 2 ${ }^{\mathrm{a}}$. ed. Rio de Janeiro: Renovar, 2000. TROTABAS, Louis; COTTERET, Jean-Marie. Droit budgétaire et comptabilité publique. $5^{\mathrm{a}}$. ed. Paris: Dalloz, 1995. 416 p.

VILLEGAS, Héctor B. Curso de finanzas, derecho financiero y tributário. $7^{\mathrm{a}}$. ed. Buenos Aires: Depalma, 2001. 977p.

VILLELA, Luiz; LEMGRUBER, Andrea; JORRATT, Michael. Los presupuestos de gastos tributários: conceptos y desafios de implementación. Washington: BID, 2009. $70 \mathrm{p}$.

VIÑUELA, Enrique García. Teoría del Gasto Público. Madrid: Minerva Ediciones, 1999. $260 \mathrm{p}$.

VIVES, Francesc Vallès. El control externo del gasto público - configuración y garantía constitucional. Madrid: Centro de Estudios Políticos y Constitucionales, 2003. 546 p. 
WIESNER, Herbert; LEIBINGER, Bodo; MÜLLER, Reinhard. Öffentliche Finanzwirtschaft. $12^{\mathrm{a}}$. ed. Tübingen: Decker, 2008. 283p.

YURRITA, Miguel Ángel Collado. Derecho Financiero. In: Sanchís, Luis Prieto (org). Introducción al Derecho. Cuenca: Universidad de Castilla - La Mancha, 1996, p. 105118.

\subsection{Sítios da Internet}

http://www.worldbank.org - Banco Mundial

http://www.constituteproject.org - Constitute Project (Google)

http://www.contaspublicas.com.br - ONG Contas Públicas

http://www.ccrek.be - Corte de Contas da Bélgica

http://www.bundesrechnungshof.de - Corte de Contas Federal da Alemanha

http://www.simone.it - Dicionário Jurídico Italiano

http://www.folha.com.br - Folha de São Paulo

http://www.imf.org - Fundo Monetário Internacional

http://www.planejamento.gov.br - Ministério do Planejamento, Orçamento e Gestão

http://www.nao.gov.uk - National Audit Office

http://www.estadao.com.br - O Estado de São Paulo

http://www.convenios.gov.br - Portal dos Convênios (Governo Federal)

http://www.portaldatransparencia.gov.br - Portal da Transparência (Governo Federal)

http://www.veja.com.br - Revista Veja

http://www.tesouro.fazenda.gov.br - Secretaria do Tesouro Nacional (STN)

http://www.orcamentofederal.gov.br/ - Secretaria de Orçamento Federal - SOF

http://www.stf.jus.br - Supremo Tribunal Federal

http://www.tcu.gov.br - Tribunal de Contas da União

\subsection{Legislação Citada}

\section{Brasil}

Constituição Federal de 1967

Emenda Constitucional $n^{\circ} 1 / 1969$

Constituição Federal de 1988

Emenda Constitucional n 19/1998 - Reforma Administrativa

Emenda Constitucional $n^{\circ}$ 25/2000 - Limites do Poder Legislativo Municipal

Emenda Constitucional n 29/2000 - Aplicação Mínima em Saúde 
Emenda Constitucional $n^{\circ} 53 / 2006$

Emenda Constitucional n 62/2009 - Regime Especial dos Precatórios

Lei $\mathrm{n}^{\circ} 4.320 / 1964$

Lei n 5.172/1966 - Código Tributário Nacional

Lei Complementar $n^{\circ}$ 82/1995 - Lei Camata

Lei Complementar n ${ }^{\circ}$ 96/1999 - Lei Camata II

Lei Complementar $n^{\circ}$ 101/2000 - Lei de Responsabilidade Fiscal

Lei Complementar $n^{\circ}$ 104/2001 - Altera o CTN

Lei Complementar $n^{\circ}$ 123/2006 - Estatuto da Microempresa e da EPP

Lei Complementar $n^{\circ}$ 131/2009 - Lei da Transparência

Lei Complementar $n^{\circ}$ 141/2012 - Regulamenta a EC n 29/2000

Lei ${ }^{\circ} 12.017 / 2009$ - LDO 2010

Lei ${ }^{\circ}$ 12.309/2010 - LDO 2011

Lei ${ }^{\circ} 12.708 / 2012$ - LDO 2013

Decreto-lei n 4.048/1942 - Criação do SENAI

Decreto-lei n ${ }^{\circ}$ 8.621/1946 - Criação do SENAC

Decreto-lei ${ }^{\circ}$ 9.403/1946 - Criação do SESI

Decreto-lei n 200/1967 - Reforma Administrativa

Decreto-lei n ${ }^{\circ}$ 201/1967 - Responsabilidade de Prefeitos e Vereadores

Lei n ${ }^{\circ}$ 8.029/1990 - Extinção e Dissolução de Entidades da Administração Federal

Lei $n^{\circ}$ 8.080/1990 - Lei Orgânica da Saúde

Lei nº 8.112/1990 - Estatuto dos Servidores Públicos Civis da União

Lei $\mathrm{n}^{\circ} 8.315 / 1991$ - Criação do SENAR

Lei ${ }^{\circ}$ 8.429/1992 - Lei de Improbidade Administrativa

Lei $n^{\circ}$ 8.443/1992 - Lei Orgânica do Tribunal de Contas da União

Lei ${ }^{\circ}$ 8.666/1993 - Lei Geral de Licitações e Contratos

Lei $n^{\circ}$ 8.706/1993 - Criação do SEST e SENAT

Lei $n^{\circ}$ 8.906/1994 - Estatudo da Ordem dos Advogados do Brasil

Lei ${ }^{\circ}$ 9.394/1996 - Lei de Diretrizes e Bases da Educação (LDB)

Lei $n^{\circ} 9.504 / 1997$ - Normas para as Eleições

Lei ${ }^{\circ}$ 9.527/1997 - Altera a Lei ${ }^{\circ} 8.112 / 1990$ 
Lei ${ }^{\circ}$ 9.637/1998 - Organizações Sociais

Lei $\mathrm{n}^{\circ}$ 9.755/1998 - Homepage Contas Públicas

Lei $n^{\circ}$ 9.784/1999 - Lei do Processo Administrativo Federal

Lei ${ }^{\circ}$ 9.790/1999 - OSCIPs e Termos de Parceria

Lei $\mathrm{n}^{\circ} 10.028 / 2000$ - Lei dos Crimes Fiscais

Lei $\mathrm{n}^{\circ} 10.520 / 2002$ - Lei do Pregão

Lei n ${ }^{\circ}$ 12.401/2011 - Assistência Terapêutica e Incorporação de Tecnologias no SUS

Lei $n^{\circ}$ 12.462/2011 - Regime de Diferenciado de Contratações Públicas (RDC)

Lei ${ }^{\circ} 12.527 / 2011$ - Lei de Acesso à Informação

Lei ${ }^{\circ}$ 12.662/2012 - Lei Geral da Copa

Lei ${ }^{\circ} 12.688 / 2012$ - Altera o RDC

Lei n 12.871/2013 - Programa "Mais Médicos"

Medida Provisória n 2.225-45/2001 - Altera a Lei n 8.112/1990

Medida Provisória n 628/2013 - Programa "Mais Médicos"

Decreto $n^{\circ}$ 15.783/1922 - Regulamento do Código de Contabilidade Pública

Decreto $n^{\circ}$ 93.872/1986 - Unificação de Recursos do Caixa do Tesouro Nacional

Decreto n 343/1991 - Concessão de Diárias no Serviço Público Civil da União

Decreto n 347/1991 - Utilização do SIAFI e SIAPE no Poder Executivo Federal

Decreto $n^{\circ}$ 2.829/1998 - Normas para elaboração do PPA 2000-2003

Decreto $n^{\circ}$ 6.170/2007 - Transferências mediante convênios e contratos de repasse

Decreto ${ }^{\circ} 7.386 / 2010$ - Estrutura do Ministério da Fazenda

Decreto $n^{\circ} 7.724 / 2012$ - Regulamenta a Lei de Acesso à Informação (LAI)

Portaria MPOG n ${ }^{\circ}$ 426, de 6/12/2007

Portaria Interministerial MP/MP/CGU n 127, de 29/5/2008

Portaria Interministerial MP/MP/CGU n ${ }^{\circ}$ 507, de 24/11/2011

Portaria MF n ${ }^{\circ} 357$, de 15/12/2012

Portaria Interministerial MS/ME ${ }^{\circ} 1.369$, de 8/7/2013

Instrução Normativa STN n 1 , de 15/1/1997

Instrução Normativa STN n 1 , de 4/5/2001 


\title{
Portugal
}

Constituição Portuguesa

Lei de Enquadramento Orçamental (LEO) - Lei n ${ }^{\circ}$ 91/2001

Lei de Organização e Processo do Tribunal de Contas (LOPTC) - Lei n 98/1997

\section{Espanha}

Constituição Espanhola

Ley General Tributária (LGT) - Lei n 58/2003

Ley General Presupuestaria (LGP) - Lei n 47/2003

\author{
Alemanha \\ Grundgesetz - Lei Fundamental Alemã \\ Haushaltsgrundsätzegesetz - Lei de Princípios Orçamentários \\ Bundeshaushaltsordung - $\mathrm{BHO}$
}

\subsection{Acórdãos e Deliberações de Tribunais}

\section{Tribunal de Contas da União}

Decisão n 40/1992 - Plenário

Decisão n 379/1993 - Plenário

Decisão n 557/1993 - Plenário

Decisão n 389/1994 - Plenário

Decisão n 411/1994 - Plenário

Decisão n 477/1994 - Plenário

Acórdão n 92/1996 - Plenário

Decisão n 19/1997 - Plenário

Decisão n 246/1997 - 1ª . Câmara

Decisão n 907/1997 - Plenário

Decisão n 461/1998 - Plenário

Acórdão n 38/1999 - Plenário

Decisão nº 299/1999 - Plenário

Decisão n 210/2000 - Plenário

Decisão $n^{\circ}$ 501/2000 - Plenário

Decisão n 1.049/2000 - Plenário 
Acórdão n ${ }^{\circ} 328 / 2001$ - $1^{\text {a }}$. Câmara

Acórdão n 523/2001 - Plenário

Decisão n 929/2001 - Plenário

Decisão nº 1.092/2001 - Plenário

Decisão n 143/2002 - Plenário

Acórdão n 767/2003 - Plenário

Acórdão n 889/2003 - Plenário

Acórdão n 1.640/2003 - Plenário

Acórdão n ${ }^{\circ}$ 1.765/2003 - Plenário

Acórdão n 338/2004 - Plenário

Acórdão n 341/2004 - Plenário

Acórdão n 421/2004 - Plenário

Acórdão n ${ }^{\circ} 778 / 2004$ - $1^{\text {a }}$. Câmara

Acórdão n 782/2004 - 1 1 $^{\text {a }}$ Câmara

Acórdão n 889/2004 - Plenário

Acórdão n 1.390/2004 - Plenário

Acórdão nº 1445/2004 - Plenário

Acórdão n 95/2005 - Plenário

Acórdão n $374 / 2005$ - $1^{\text {a }}$. Câmara

Acórdão n 1.718/2005 - Plenário

Acórdão n ${ }^{\circ}$ 998/2006 - 2a . Câmara

Acórdão n ${ }^{\circ}$ 1.366/2006 - Plenário

Acórdão n 1.370/2006 - Plenário

Acórdão n 2.066/2006 - Plenário

Acórdão n 2.077/2006 - 2 ${ }^{\mathrm{a}}$. Câmara

Acórdão n 2.332/2006 - Plenário

Acórdão n ${ }^{\circ}$ 2.649/2006 - 1 ${ }^{\text {a }}$. Câmara

Acórdão n ${ }^{\circ} 3.548 / 2006$ - 1ª . Câmara

Acórdão n ${ }^{\circ}$ 1.241/2007 - $1^{\text {a }}$. Câmara

Acórdão n ${ }^{\circ}$ 60/2011 - Plenário

Acórdão n 3.071/2012 - Plenário 


\section{Supremo Tribunal Federal}

Súmula Vinculante $\mathrm{n}^{\circ} 6$

Súmula Vinculante ${ }^{\circ} 15$

Súmula Vinculante ${ }^{\circ} 16$

Súmula Vinculante ${ }^{\circ} 17$

Súmula Vinculante $\mathrm{n}^{\circ} 20$

AC 1915 REF-MC/RJ

$\mathrm{AC} \mathrm{n}^{\circ} 4.094 / \mathrm{MC}$ - DF

ADI n ${ }^{\circ} 1.480-\mathrm{MC}$

ADI n 3026

ADI $n^{\circ} 4.048$ - MC/Df

ADI n 4094/MC

$\mathrm{AI} \mathrm{n}^{\circ} 360461 \mathrm{AgR} / \mathrm{MG}$

MS n 21.797

$\mathrm{MS} \mathrm{n}{ }^{\circ} 28.469-\mathrm{AgR}$ - segundo/DF

$\mathrm{RE} \mathrm{n}^{\circ} 34.518 / \mathrm{DF}$

$\mathrm{RE} \mathrm{n}^{\circ} 71.154 / \mathrm{PR}$

$\mathrm{RE} \mathrm{n}^{\circ} 75.908 / \mathrm{PR}$

$\mathrm{RE} \mathrm{n}^{\circ}$ 80.004/SE

$\mathrm{RE} \mathrm{n}^{\circ} 405.386 / \mathrm{RJ}$

$\mathrm{RE} \mathrm{n}^{\circ} 466.343 / \mathrm{SP}$

\section{Superior Tribunal de Justiça}

Súmula nº 208 - STJ

$\operatorname{AgRg} n^{\circ} 1237139 / \mathrm{PE}$

Ação Penal n 480/MG

Resp n ${ }^{\circ} 1145001 / \mathrm{RS}$

$\mathrm{MS} \mathrm{n}^{\circ} 13.750 / \mathrm{DF}$

Resp n ${ }^{\circ} 1090707 / \mathrm{SP}$

AgRg nos EDcl no Resp n ${ }^{\circ} 727966 / \mathrm{SP}$

Resp n ${ }^{\circ} 37.275 / \mathrm{SP}$ 
